\begin{tabular}{|c|l|}
\hline Title & Carbon dioxide exchange of a larch forest after a ty phoon disturbance \\
\hline Author(s) & Sano, Tomohito; Hirano, Takashi; Liang, Naishen; Hirata, Ryuichi; Fujinuma, Y asumi \\
\hline Citation & $\begin{array}{l}\text { Forest Ecology and Management, 260(12), 2214.2223 } \\
\text { https://doi.org/10.1016j.foreco.2010.09.026 }\end{array}$ \\
\hline Issue Date & 2010-12-15 \\
\hline Doc URL & http://hdl.handle.net/2115/45748 \\
\hline Type & article(author version) \\
\hline File Information & hirano2.pdf (本文) \\
\hline
\end{tabular}

Instructions for use 


\section{Carbon dioxide exchange of a larch forest after a typhoon disturbance}

Tomohito Sano $^{\mathrm{a}, *}$, Takashi Hirano ${ }^{\mathrm{a}}$, Naishen Liang ${ }^{\mathrm{b}}$, Ryuichi Hirata $^{\mathrm{a}}$, Yasumi Fujinuma ${ }^{\mathrm{c}}$

${ }^{a}$ Graduate School of Agriculture, Hokkaido University, Kita-9 Nishi-9, Kita-ku, Sapporo-City, Hokkaido, 060-8589 Japan

${ }^{\mathrm{b}}$ Center for Global Environmental Research, National Institute for Environmental Studies, 16-2 Onogawa, Tsukuba-City, Ibaraki, 305-8506 Japan

${ }^{\mathrm{c}}$ Tottori University of Environmental Studies, 1-1 Wakabadai Kita-1, Tottori-City, Tottori, 689-1111 Japan

* Corresponding author. Tel.: +81-11-706-4175; Fax: +81-11-706-2494.

E-mail addresses: sanotomo@env.agr.hokudai.ac.jp (T. Sano) 


\section{Abstract}

A typhoon event catastrophically destroyed a 45-year-old Japanese larch plantation in southern Hokkaido, northern Japan in September 2004, and about 90\% of trees were blown down. Vegetation was measured to investigate its regeneration process and $\mathrm{CO}_{2}$ flux, or net ecosystem production (NEP), was measured in 2006-2008 using an automated chamber system to investigate the effects of typhoon disturbance on the ecosystem carbon balance. Annual maximum aboveground biomass (AGB) increased from $2.7 \mathrm{Mg}^{-1}$ in 2006 to 4.0 $\mathrm{Mg} \mathrm{ha}^{-1}$ in 2007, whereas no change occurred in annual maximum leaf area index (LAI), which was $3.7 \mathrm{~m}^{2} \mathrm{~m}^{-2}$ in 2006 and $3.9 \mathrm{~m}^{2} \mathrm{~m}^{-2}$ in 2007. Red raspberry (Rubus idaeus) had become dominant within 2 years after the typhoon disturbance, and came to account for about $60 \%$ and $50 \%$ of AGB and LAI, respectively. In comparison with $\mathrm{CO}_{2}$ fluxes measured by the eddy covariance technique in 2001-2003, for 4.5 months during the growing season, the sum of gross primary production (GPP) decreased on average by $739 \mathrm{gC} \mathrm{m}^{-2}(64 \%)$ after the disturbance, whereas ecosystem respiration (RE) decreased by $501 \mathrm{gC} \mathrm{m}^{-2}(51 \%)$. As a result, NEP decreased from $159 \pm 57 \mathrm{gC} \mathrm{m}^{-2}$ to $-80 \pm 30 \mathrm{gC} \mathrm{m}^{-2}$, which shows that the ecosystem shifted from a carbon sink to a source. Seasonal variation in RE was strongly correlated to soil temperature. The interannual variation in the seasonal trend of RE was small. Light-saturated GPP $\left(P_{\max }\right)$ decreased from $30-45 \mu \mathrm{mol} \mathrm{m} \mathrm{m}^{-2}$ to $8-12 \mu \mathrm{mol} \mathrm{m} \mathrm{m}^{-2} \mathrm{~s}^{-1}$ during the summer season through the disturbance because of large reduction in LAI.

Keywords: automated chamber system, carbon dioxide, disturbance, larch forest, red raspberry, typhoon

\section{Introduction}

Severe disturbances by fire, insects, disease, windthrow and harvesting significantly 
affect the carbon balance of forest ecosystems (Magnani et al., 2007; Baldocchi, 2008; Amiro et al., in press). Many studies have focused on the change of forest structure, vegetation composition, and regeneration processes by severe wind damage (Foster and Boose, 1992; Merrens and Peart, 1992; Toyooka et al., 1992; Yoshida and Noguchi, 2009; Takafumi and Hiura, 2009; Wang et al., 2010). However, few reports have described direct quantification of the change of carbon balance. In Western Europe, windthrow by storms is an important forest disturbance (Nilsson et al., 2004; Usbeck et al., 2010). Lindroth et al. (2009) reported that the annual net ecosystem production (NEP) of a Swedish forest in the first year after the Gudrun storm event was estimated to be from -897 to $-1259 \mathrm{gC} \mathrm{m}^{-2}$ year $^{-1}$, and it was much more carbon loss than that of clear-cut forest in Europe, which ranged between ca. -400 and -100 $\mathrm{gC} \mathrm{m}^{-2}$ year $^{-1}$ (Kowalski et al., 2004). Knohl et al. (2002) also reported that about $50 \mathrm{gC} \mathrm{m}^{-2}$ was released in the western Russian taiga during the summer season ( 3 months) 2 years after a windthrow event. These changes to large carbon sources after windthrow can be mainly explained by decreased photosynthesis attributable to vegetation reduction and increased heterotrophic respiration from disturbed soil and produced wood and leaf debris.

Typhoon is an important disturbance agent in East Asia and has sometimes caused catastrophic wind damage to forest ecosystems there. Typhoon Toyamaru severely damaged 750,000 ha of forest area and blew down 27 million $\mathrm{m}^{3}$ of stem wood in Hokkaido, the northernmost island of Japan, in 1954 (Tamate, 1977). Typhoon Songda hit Hokkaido again in September 2004 and left 37,000 ha of devastated forest (Hokkaido Forestry Research Institute, 2004). Other forests in East Asia, such as those in southwestern Japan (Saito, 2002) and Taiwan (Mabry et al., 1998; Lee et al., 2008), have also been struck frequently by typhoons. It is important to clarify how typhoon disturbances affect carbon dynamics in forest ecosystems, because the number of intense tropical cyclones is expected to increase as a result of global warming (IPCC, 2007). Furthermore, the occurrence of wind damage will potentially increase 
in Japanese forests, because mature forest increases owing to less cutting (Fujimori, 1995; Kuboyama et al., 2003). Yamanoi et al. (2009) reported that a deciduous broadleaf forest in Hokkaido changed from a carbon sink to a source after Typhoon Songda, which destroyed more than $50 \%$ of crown areas. Sanada et al. (1996) showed that the soil carbon content in A-horizon had increased or varied randomly in the forest of central Hokkaido by Typhoon Toyamaru. However, few reports have quantified the change of carbon balance after typhoon disturbance in East Asia.

Tomakomai Flux Research Site was a larch plantation, and NEP had been measured by the eddy covariance technique since 2000 (Hirano et al., 2003; Wang et al., 2004; Hirata et al., 2007). After removing trees blown down by Typhoon Songda in 2004, red raspberry (Rubus idaeus) grew rapidly and became dominant. After the typhoon disturbance, NEP has been measured using a multichannel automated chamber system (Liang et al., 2003, 2004). The aims of this study were: (1) to elucidate the initial change of vegetation and microclimate following typhoon damage, (2) to quantify ecosystem carbon fluxes of the disturbed ecosystem and (3) to investigate the disturbance effect on the carbon balance of the larch forest.

\section{Materials and methods}

\subsection{Site description}

The study was conducted at Tomakomai Flux Research Site $\left(42^{\circ} 44^{\prime} \mathrm{N}, 141^{\circ} 31^{\prime} \mathrm{E} ; 125\right.$ m above sea level) in the Tomakomai National Forest in southern Hokkaido, Japan. This site is one of the core sites of AsiaFlux network. The forest was a Japanese larch (Larix kaempferi) plantation that had been afforested in 1957-1959 after Typhoon Toyamaru in 1954. The area was about 100 ha, and its canopy height was about $15 \mathrm{~m}$ in 2004 . The terrain is essentially flat with a slight slope of $1-2^{\circ}$. Some deciduous broadleaf trees such as birch 
(Betula ermanii, Betula platyphylla) and Japanese elm (Ulmus japonica) had invaded into the larch plantation, and a few spruce trees (Picea jezoensis) were scattered. Basal area densities of trees with a stem diameter at breast height $(\mathrm{DBH}, 1.3 \mathrm{~m})$ larger than $5 \mathrm{~cm}$ were 19.6 and $5.5 \mathrm{~m}^{2} \mathrm{ha}^{-1}$ for larch and other trees, respectively, in 2004. The maximum leaf area index (LAI) of larch and other trees were, respectively, 3.3 and $2.5 \mathrm{~m}^{2} \mathrm{~m}^{-2}$ in 2003 (Takeda et al., 2008). Dominant understory species were Dryopteris crassirhizoma, Dryopteris austriaca, Pachysandra terminalis and Hydrangea petiolaris. The maximum aboveground biomass (AGB) and LAI of the understory species were $2.7 \mathrm{Mg} \mathrm{ha}^{-1}$ (Yuzu et al., 2003) and $3.6 \mathrm{~m}^{2} \mathrm{~m}^{-2}$, respectively.

Mean annual temperature was $7.5^{\circ} \mathrm{C}$, and monthly-mean temperature varied from $-4.1^{\circ} \mathrm{C}$ in January to $20.3^{\circ} \mathrm{C}$ in August, during $1971-2000$ at Tomakomai weather station, which was about $10 \mathrm{~km}$ apart from the study site. Annual precipitation was $1228 \mathrm{~mm}$ and high in the summer.

The soil was volcanogenous regosol with $1-2 \mathrm{~cm}$ thick fresh litter and a 5-10 cm-thick decomposed organic layer, which accounted for $95 \%$ of soil organic carbon within a depth of $1 \mathrm{~m}$ (Matsuura and Sasa, 2000).

Typhoon Songda hit the site and blew down more than $90 \%$ of trees on 8 September 2004. Most of the fallen trees were uprooted. The soil surface was roughly disturbed. Two observation towers were destroyed and all observations, such as tower based $\mathrm{CO}_{2}$ flux and ground based chamber measurements, were forced to be ceased. After the typhoon, the tree stems were removed from the forest for timber and wood chip, whereas branches and uprooted stumps were left. A new plot of 1.4 ha $(140 \mathrm{~m} \times 100 \mathrm{~m})$ was replaced in the study site in 2005.

\subsection{Vegetation survey}


We set 10 rectangular plots $(1 \mathrm{~m} \times 10 \mathrm{~m})$. Each plot was divided into 10 subplots $(1$ $\mathrm{m} \times 1 \mathrm{~m})$. Aboveground vegetation was harvested from one subplot of each rectangular plot, which totalled to 10 subplots, every 1 or 2 months from May or June through December in 2006 and in 2007. The harvested vegetation was sorted by species, and divided into leaf, stem, and fruit parts. AGB was determined after drying each part at $80^{\circ} \mathrm{C}$ for $48 \mathrm{~h}$ in an oven. Some leaves of each species were used to determine specific leaf area (SLA), which was calculated as the ratio of leaf area to leaf dry weight. Leaf area was measured using an optical scanner and software (Lia for Win32, ver. 0.376ß1; Yamamoto, available via http://www.agr.nagoya-u.ac.jp/ shinkan/LIA32/index.html). LAI was calculated by multiplying the leaf biomass by SLA.

Biomass of larch and other trees before the typhoon were calculated from DBH using allometric regression equations. The $\mathrm{DBH}$ values of all trees with $\mathrm{DBH}$ larger than $5 \mathrm{~cm}$ were measured within an area of 1 ha in 2004. The allometric regression equation of larch trees was derived from data of harvesting surveys conducted in 2000 and 2001. For broadleaf trees, the allometric equation was derived from harvest data (Takahashi et al., 1999) of the Tomakomai Experimental Forest of Hokkaido University, which located within $6 \mathrm{~km}$ of the study site. The seasonal change of overstory LAI was determined from the attenuation of short-wave radiation by Beer's law using an extinction coefficient of 0.58 and the wood area index of 1.4 $\mathrm{m}^{2} \mathrm{~m}^{-2}$ before the disturbance (Hirata et al., 2007). Understory vegetation was assessed monthly during June-November in 2001 (Yuze et al., 2003).

\subsection{Microclimate measurements}

Microclimate has been measured on a 3.5-m-tall mast since August 2005. Four components of radiation, downward and upward short-wave and long-wave radiations, were measured at $2.8 \mathrm{~m}$ height using a radiometer (CNR1; Kipp \& Zonen, the Netherlands). 
Photosynthetic photon flux density (PPFD) was measured at $2.8 \mathrm{~m}$ using a quantum sensor (LI-190; Li-Cor Inc., USA). Precipitation was measured at $1.5 \mathrm{~m}$ using tipping-bucket rain gauge (TE525MM; Campbell Scientific Inc., USA). Wind speed and direction were measured at $3.8 \mathrm{~m}$ using a wind vane anemometer (3002; R. M. Young Co., USA). Air temperature and relative humidity were measured at 2.6 and $1.2 \mathrm{~m}$ using platinum resistance thermometers and capacitive hygrometers (HMP45A; Vaisala, Finland) in radiation shields (DTR502B; Vaisala, Finland). Soil temperature and volumetric soil moisture were measured at four points around the mast. Soil temperature was measured at $0.01,0.03,0.06,0.15$, and $0.50 \mathrm{~m}$ depth with copper-constantan thermocouples. Soil moisture was measured at 0.01-0.05 $\mathrm{m}$ depth using TDR sensors (CS615; Campbell Scientific Inc., USA). Signals from the sensors were taken every $5 \mathrm{~s}$; then their 5-min means were recorded using a datalogger (CR10X; Campbell Scientific Inc., USA).

Similar microclimate variables had been monitored on the tower (42 $\mathrm{m}$ height) and on the forest floor within $30 \mathrm{~m}$ from the tower since July 2000 until the typhoon disturbance. Four components of radiation, downward and upward short-wave and long-wave radiations, were measured at 41,17 and $2 \mathrm{~m}$ height. PPFD was measured at 41, 17, 4 and $2 \mathrm{~m}$. Precipitation was measured at 41 and $1.5 \mathrm{~m}$. Wind speed and direction were measured at 42 , 27, 22 18, 14, 8, 5 and 1.5m. Air temperature and relative humidity were measured at 41, 27, $22,18,14,8,5$ and $1.5 \mathrm{~m}$. Soil temperature was measured at $0.05,0.10,0.20$ and $0.50 \mathrm{~m}$ depth. Soil moisture was measured at 0.05 and $0.10 \mathrm{~m}$. Hirano et al. (2003) provides details of the microclimate measurements.

\subsection{Measurement of $\mathrm{CO}_{2}$ flux}

NEP was measured using a multichannel automated closed chamber system (Liang et al, 2003, 2004) at 30-min intervals from May or June through November in 2006, 2007 and 
2008 after the typhoon disturbance. The chamber system adopted a flow-through, non-steady-state design. The system comprised six automated chambers in 2006 or four in 2007 and 2008. The chambers were cubes $(0.9 \mathrm{~m} \times 0.9 \mathrm{~m} \times 0.9 \mathrm{~m})$ and covered a ground area of 4.9 in 2006 or $3.2 \mathrm{~m}^{2}$ in 2007 and 2008 in total. The chambers were constructed of clear PVC (1 mm thick) glued to a frame made from plastic-coated steel pipe. Between measurements, the two sections of the chamber lid were raised vertically to allow precipitation and leaf litter to reach the enclosed soil surface, thus keeping the soil conditions as natural as possible. The chamber lids were raised and closed by two pneumatic cylinders at a pressure of about $0.2 \mathrm{MPa}$, which was generated by a micro-compressor. During the measurement, the chamber was closed and the chamber air was mixed by two micro-blowers. The chamber air was circulated through an infrared gas analyzer (LI-820; Li-Cor Inc., USA) by a micro-diaphragm pump (CM-50; Enomoto Ltd., Tokyo, Japan) at $5 \mathrm{~L} \mathrm{~min}^{-1}$.

All chambers were installed on the ground with vegetation to measure NEP and randomly set around the mast within $40 \mathrm{~m}$. Over the course of $30 \mathrm{~min}$, all chambers were closed sequentially by a home-made relay board controlled by a datalogger (CR10X; Campbell Scientific Inc., USA). We set the sampling period for each chamber to $225 \mathrm{~s}$. Therefore, the chambers were open for $87.5 \%$ of the time. Thus, the interior of each chamber had good exposure to the atmospheric.

A linear equation was fitted to the time series of $\mathrm{CO}_{2}$ concentration using the least-square method, and the rate $\mathrm{CO}_{2}$ change $\left(\Delta C / \Delta t, \mu \mathrm{mol} \mathrm{mol}{ }^{-1} \mathrm{~s}^{-1}\right)$ was determined. NEP $\left(\mu \mathrm{mol} \mathrm{m} \mathrm{s}^{-1}\right)$ of each chamber was calculated using the following equation.

$$
\mathrm{NEP}=-\frac{\Delta C}{\Delta t} \cdot \frac{V}{V_{\mathrm{air}}\left(273.2+T_{\mathrm{a}}\right) / 273.2} \cdot \frac{1}{A}
$$

In that equation, $V$ is chamber volume $\left(0.729 \mathrm{~m}^{3}\right), V_{\text {air }}$ is molar volume of air at $0^{\circ} \mathrm{C}(0.0224$ $\left.\mathrm{m}^{3} \mathrm{~mol}^{-1}\right), T_{\mathrm{a}}$ is air temperature $\left({ }^{\circ} \mathrm{C}\right)$ measured on the mast at $1.2 \mathrm{~m}$ height and $A$ is ground area covered by the chamber $\left(0.81 \mathrm{~m}^{2}\right)$. The volume of plants in the chamber was negligible 
$(<1 \%$ of $V)$.

NEP data were excluded when the chamber malfunctioned because of problems such as gnawed air tube by animals or damage to the chamber by severe wind. Next, we calculated the mean and standard deviation (SD) values of half-hourly NEP for each chamber at a half-monthly or a monthly interval, and each half-hourly NEP was excluded when it was beyond the range of mean $\pm 2 \mathrm{SD}$.

We used $\mathrm{CO}_{2}$ flux data measured by the eddy covariance technique using a closed-path system at $27 \mathrm{~m}$ on a tower before the typhoon (Hirata et al., 2007). Wind speed and virtual temperature were measured with a three-dimensional sonic anemometer-thermometer (DA-600-3TV (Probe TR-61C); Kaijo Corp., Tokyo, Japan). $\mathrm{CO}_{2}$ and water vapor fluctuations were measured using a closed-path $\mathrm{CO}_{2} / \mathrm{H}_{2} \mathrm{O}$ analyzers (LI6262; Li-Cor Inc., USA). Air was sampled near the anemometer and pumped into the gas analyzer through Dekoron tubes. Data were sampled at $10 \mathrm{~Hz}$ and logged using a datalogger (DR-M3; Teac Corp., Japan). Half-hourly NEP was calculated as the sum of the eddy $\mathrm{CO}_{2}$ flux and the rate of change in $\mathrm{CO}_{2}$ storage below the height of the eddy covariance system. Hirata et al. (2007) provides details of the measurement, calculation, quality control and gap filling of eddy flux data and the partition of eddy NEP into gross primary production or ecosystem photosynthesis (GPP) and ecosystem respiration (RE).

\subsection{NEP partition and gap filling}

Daytime NEP measured with the chamber system was partitioned into RE and GPP by the following empirical methods.

$\mathrm{RE}$ is $\mathrm{CO}_{2}$ emission by autotrophic and heterotrophic respirations. Daytime RE was extrapolated from soil temperature using the relation between NEP at night (PPFD $<10 \mu \mathrm{mol}$ $\left.\mathrm{m}^{-2} \mathrm{~s}^{-1}\right)$ and temperature shown below: 


$$
\mathrm{RE}=\mathrm{RE}_{10} \exp \left[\alpha\left(T_{\mathrm{s}}-10\right)\right]
$$

In that equation, $\mathrm{RE}_{10}$ is a constant or $\mathrm{RE}$ at reference temperature of $10{ }^{\circ} \mathrm{C}, \alpha$ is a constant and $T_{\mathrm{s}}$ is soil temperature $\left({ }^{\circ} \mathrm{C}\right)$ at $0.06 \mathrm{~m}$ depth. Negative NEP at night was equivalent to RE $(\mathrm{RE}=-\mathrm{NEP})$ because of no $\mathrm{CO}_{2}$ uptake through photosynthesis. Parameter values were obtained using the least-square method for each of two periods (June-September and October-November) in 2006 and 2008, or three periods (May-June, July-September and October-November) in 2007, considering vegetation phenology. RE value was set to zero if calculation was negative. The temperature sensitivity $\left(Q_{10}\right)$ of RE was determined from the parameter $\alpha$ of Eq. (2).

GPP was calculated as the sum of RE and NEP (GPP = NEP + RE). GPP was set to zero if the sum was negative. Gaps of NEP data were filled with the sum of calculated RE using Eq. (2) and calculated GPP using a non-rectangular hyperbola equation (Thornley, 1976) shown below.

$$
\mathrm{GPP}=\frac{\varphi \cdot \mathrm{PPFD}+P_{\max }-\sqrt{\left(\varphi \cdot \mathrm{PPFD}+P_{\max }\right)^{2}-4 \varphi \cdot \mathrm{PPFD} \cdot \theta \cdot P_{\max }}}{2 \theta}
$$

In that equation, $\varphi\left[\mathrm{mol}(\mathrm{mol} \text { photon })^{-1}\right]$ is the initial slope of the curve, $P_{\max }\left(\mu \mathrm{mol} \mathrm{m} \mathrm{m}^{-2} \mathrm{~s}^{-1}\right)$ is the maximum GPP at light saturation, $\theta$ is the convexity of the equation. This equation was obtained using the least-square method every week, 2 weeks or month considering vegetation phenology.

The value of NEP is positive or negative when the ecosystem functions as a net $\mathrm{CO}_{2}$ sink (GPP > RE) or a source (GPP < RE).

\section{Results}

\subsection{Vegetation change}

The annual maximum AGB before the typhoon was estimated at $91.8 \mathrm{Mg} \mathrm{ha}^{-1}$. However, it decreased drastically to $2.7 \mathrm{Mg} \mathrm{ha}^{-1}$ in 2006 , because most of the trees were 
blown down by the typhoon wind. The annual maximum LAI was $9.4 \mathrm{~m}^{2} \mathrm{~m}^{-2}$, which comprised $5.8 \mathrm{~m}^{2} \mathrm{~m}^{-2}$ from tree species (Takeda et al., 2008) and $3.6 \mathrm{~m}^{2} \mathrm{~m}^{-2}$ from understory species before the typhoon, and decreased to $3.7 \mathrm{~m}^{2} \mathrm{~m}^{-2}$ in 2006 . Consequently, LAI was decreased by $61 \%$, whereas AGB was decreased by $97 \%$. The AGB and LAI were equivalent to those of understory vegetation before the typhoon.

In the initial stage of succession following the disturbance, annual maximum AGB increased from 2.7 $\mathrm{Mg} \mathrm{ha}^{-1}$ in 2006 to $4.0 \mathrm{Mg} \mathrm{ha}^{-1}$ in 2007, whereas the annual maximum LAI did not vary significantly, with $3.7 \mathrm{~m}^{2} \mathrm{~m}^{-2}$ in 2006 and $3.9 \mathrm{~m}^{2} \mathrm{~m}^{-2}$ in 2007 (Fig. 1). R. idaeus accounted for about 60\% of total AGB in July 2006 and 2007, and Dryopteris crassirhizoma, Pachysandra terminalis, Solidago gigantea and grass plants each accounted for less than $10 \%$. Similarly, regarding LAI, $R$. idaeus, grass plants and other each species accounted for about $50 \%, 20 \%$ and less than 10\%, respectively. Seedlings of tree species, such as Betula platyphylla, Betula maximowicziana, Larix kaempferi, Maackia amurensis, Magnolia hypoleuca and Acer pictum were also found, whereas their AGB and LAI were very small. Seasonal variations of AGB and LAI differed between 2006 and 2007 (Fig. 1). AGB and LAI peaked later in 2006 than in 2007.

\subsection{Microclimate change}

Table 1 and Figure 2 show mean values of meteorological data for the 3 years before the typhoon (2001-2003) and the values of each year after that (2006-2008). We compared microclimate during the same period when $\mathrm{CO}_{2}$ flux was measured from 28 June to 11 November. PPFD was lower before the typhoon than after the typhoon by $13 \%$ on an average. Precipitation was lower in 2007 and 2008 than before the typhoon. Particularly, precipitation in 2007 was about half that before the typhoon. Soil moisture decreased by $11 \%$ after the typhoon. We compared air temperatures at $14 \mathrm{~m}$ and $1.2 \mathrm{~m}$, because each temperature was 
measured around the canopy height. The air temperature was higher after the disturbance. Daytime VPD around the canopy was 50\% higher after the typhoon partly because of higher air temperature. In addition, soil temperatures in the growing season during May-September were higher after the disturbance. However, the daily amplitude gradually decreased for the 3 years, mainly because of vegetation recovery.

\subsection{Dependence of $\mathrm{CO}_{2}$ fluxes on vegetation and microclimate}

Table 2 shows the parameters of $\mathrm{RE}_{10}$ and $Q_{10}$ determined from Eq. (2) during the same period (28 June-11 November). After the disturbance, $\mathrm{RE}_{10}$ did not vary yearly, whereas $Q_{10}$ in 2006 was significantly smaller than those of other 2 years $(p<0.001)$. The mean $\mathrm{RE}_{10}$ decreased from 3.7 to 1.3 before and after the disturbance, whereas there was no significant difference in $Q_{10}$.

Nighttime RE, which is equivalent to the opposite-sign value of nighttime NEP, was normalized using the following equation according to Law et al. (1999) to eliminate its temperature response:

$\mathrm{RE}_{T, 10}=\mathrm{RE} \exp \left[\alpha\left(10-T_{\mathrm{s}}\right)\right](4)$

Therein, $\mathrm{RE}_{T, 10}$ is normalized $\mathrm{RE}$ at $10^{\circ} \mathrm{C}$, and $\alpha$ is a constant derived from Eq. (2). After the typhoon, normalized RE showed significant positive correlations with soil moisture during July-September, whereas there were poor correlations before the typhoon (Fig. 4). Liang et al. (2004) also observed that soil respiration poorly correlated with soil moisture at this site before the disturbance.

Figure 5 shows seasonal variations in $P_{\max }$ derived from Eq. (3) after the disturbance. $P_{\max }$ reached the annual maximum in July in 2006, whereas that in 2007 reached the maximum in June. In 2008, $P_{\max }$ was the largest in early July when the measurement began. The maximum value of $14.8 \pm 0.9 \mu \mathrm{mol} \mathrm{m} \mathrm{m}^{-2} \mathrm{~s}^{-1}$ in 2007 was higher than that of $10.8 \pm 2.9$ 
$\mu \mathrm{mol} \mathrm{m} \mathrm{m}^{-2}$ in 2006. However, $P_{\max }$ showed no significant difference from July through September among 2006, 2007 and 2008, and remained at $8-12 \mu \mathrm{mol} \mathrm{m} \mathrm{m}^{-2} \mathrm{~s}^{-1}$. Then, $P_{\max }$ decreased drastically in October through defoliation, whereas $P_{\max }$ decreased later in 2006 than other 2 years. Before the disturbance, $P_{\max }$ reached a plateau in June-September at 30-45 $\mu \mathrm{mol} \mathrm{m} \mathrm{s}^{-1}$ (Hirata et al., 2007), which was three to four times higher after the disturbance.

The ratios of $P_{\max }$ to total LAI including canopy and understory species were calculated every month or 2 months during July-September before and after the disturbance. The ratios little differed between 2006 and 2007, which were 2.9 and $3.2 \mu \mathrm{mol} \mathrm{m} \mathrm{m}^{-2}$ on average, respectively. Such values were lower than $5.0 \mu \mathrm{mol} \mathrm{m} \mathrm{m}^{-2} \mathrm{~s}^{-1}$ before the disturbance.

Daytime NEP at PPFD > $1000 \mu \mathrm{mol} \mathrm{m} \mathrm{s}^{-1}$ was plotted against VPD to eliminate the effect of PPFD (Fig. 6). Actually, NEP was light-saturated under such high PPFD. Significant negative correlation between light-saturated NEP and VPD was found during July-September both before and after the typhoon. The negative relationship of $\mathrm{CO}_{2}$ uptake has been already reported at this site before the disturbance (Wang et al., 2004; Ide et al., 2010), whereas VPD was generally low.

\subsection{Seasonal variations in $\mathrm{CO}_{2}$ fluxes}

Figure 7 shows seasonal variations in $\mathrm{CO}_{2}$ fluxes after the typhoon. In 2006 NEP increased close to zero in July, and decreased to the minimum $\left(-2.4 \pm 1.2 \mathrm{gC} \mathrm{m}^{-2} \mathrm{~d}^{-1}\right)$ in August. In contrast, NEP remained positive from May through mid-July in 2007. The value of NEP reached the maximum $\left(2.5 \pm 0.5 \mathrm{gC} \mathrm{m}^{-2} \mathrm{~d}^{-1}\right)$ in June, and decreased to $-1.6 \pm 0.8 \mathrm{gC} \mathrm{m}^{-2}$ $\mathrm{d}^{-1}$ in August. In 2008, NEP decreased to the minimum $\left(-1.6 \pm 1.2 \mathrm{gC} \mathrm{m}^{-2} \mathrm{~d}^{-1}\right)$ in early August, although NEP was not measured before July. After August, seasonal variations in NEP were similar among the 3 years. The value of NEP increased to nearly zero in late September and decreased thereafter. Seasonal variations in RE was accompanied by the variation of soil 
temperature and RE reached the maximum in August (Figs. 2d, 7c). Interannual variation in the seasonal trend of RE was small. The values of GPP reached the annual maximum values in August 2006 and in late June 2007, respectively. The maximum GPP was 1.3 times larger in 2007 than in 2006. In 2008, GPP was the largest in early July when the measurement began. However, GPP showed no significant difference in August among 2006, 2007 and 2008. From September to early October, GPP decreased gradually, and decreased drastically in late October through defoliation.

Seasonal sums of NEP, GPP and RE for the same period, from 28 June to 11 November, showed no significant difference among 2006, 2007 and 2008 (Table 1). The sums of GPP decreased on average by $739 \mathrm{gC} \mathrm{m}^{-2}$ (64\%) after the disturbance, whereas RE decreased by $501 \mathrm{gC} \mathrm{m}^{-2}(51 \%)$. As a result, seasonal sums of NEP decreased from $159 \pm 57$ $\mathrm{gC} \mathrm{m}^{-2}$ to $-80 \pm 30 \mathrm{gC} \mathrm{m}^{-2}$. The NEP values show that this site changed from a carbon sink to a source after the disturbance for the period of 4.5 months. In 2007 , however, $\mathrm{CO}_{2}$ emission is mitigated, if May and June are included (Table 1, Fig. 7).

\section{Discussion}

\subsection{Dependence of $\mathrm{CO}_{2}$ fluxes on vegetation and microclimate}

The lag of 2 months in the occurrence of maximum GPP and $P_{\max }$ between the second and third years, 2006 and 2007, after the disturbance would be due to the initial stage of vegetation succession and R. idaeus phenology (Figs. 5, 7b). Most stems of $R$. idaeus were composed of primocane (first-year stem) in 2006, whereas floricane (second-year stem) was equally abundant as primocane in 2007. Although primocane grows and maintains leaves from spring through autumn, floricane develops leaves in spring, and produces fruits and dies in summer (Whitney, 1982). This early defoliation of floricane inhibited total LAI from increasing during the summer in 2007 and resulted in almost identical $P_{\max }$ to that of 2006 
(Figs. 1, 5). Seasonal variations of GPP and $P_{\max }$ in May-June 2008 were considered similar to those in 2007 because R. idaeus was expected to be abundant for about 10 years after the stand-replacing disturbance (Toyooka et al., 1992; Archambault et al., 1998).

The values of $P_{\max }$ in July-September after the disturbance were one-third to one-fourth of those before the disturbance. This reduction in $P_{\max }$ would result from the reduction in LAI as well as leaf photosynthesis capacity, because the ratio of $P_{\max }$ to LAI decreased from $5.0 \mu \mathrm{mol} \mathrm{m} \mathrm{m}^{-2}$ to $2.9-3.2 \mu \mathrm{mol} \mathrm{m} \mathrm{m}^{-2}$ by the disturbance.

VPD directly affected NEP, because higher VPD causes lower stomatal conductance and, consequently, decreases photosynthesis. Although the sensitivity of NEP to VPD was higher before the typhoon (Fig. 6), the daytime VPD was 1.5 times larger after that. Thus, VPD was an important meteorological factor to control $\mathrm{CO}_{2}$ uptake even after the typhoon.

Seasonal variations in RE were mainly accompanied by variation of soil temperature (Figs. 2d, 7c), and there was little interannual variation in RE among the 3 years (Table 1). However, the temperature sensitivity $\left(Q_{10}\right)$ of RE increased from 2006 to 2007 and 2008 (Table 2). It was reported that $Q_{10}$ decreased with the decline of soil moisture (Reichstein et al., 2002). We found significant positive correlations between RE and soil moisture in July-September after the disturbance (Fig. 4). However, soil moisture cannot explain the interannual variation of $Q_{10}$, because soil moisture was not different among the 3 years (Table 1, Fig. 2e). The increase in $Q_{10}$ may result from the increase in the contribution of root respiration to RE, because $Q_{10}$ of root respiration would be higher than that of heterotrophic respiration (Boone et al., 1998). Toyooka and Sugawara (1980b) observed that both AGB and belowground biomass (BGB) of R. idaeus increased more than twice from second-year to third-year in a cultivation experiment. The BGB of R. idaeus probably increased from 2006 to 2007, because AGB increased by $49 \%$. The increase in BGB led to increase root respiration and its contribution to RE, and consequently changed the temperature sensitivity of RE. 
However, this interpretation disagree with the stability of heterotrophic respiration throughout the forest life cycle suggested by other studies (Law et al., 2003; Goulden et al., in press), because RE did not vary for 3 years after the disturbance. If autotrophic respiration increased, it must be compensated by a decrease in heterotrophic respiration. If autotrophic respiration did not vary, the contribution of growth respiration to autotrophic respiration might decrease following rapid regeneration of vegetation, because growth respiration is less sensitive to temperature, whereas maintenance respiration affected by temperature (Szaniawski and Kielkiewicz, 1982; van Iersel, 2003). The increase of vegetation might affect the temperature dependence of RE through litter supply. The floricane of $R$. idaeus supplied fresh litter during the summer in 2007 and 2008, which would increase $Q_{10}$.

\subsection{Effects of typhoon disturbance on $\mathrm{CO}_{2}$ budget}

The typhoon blew down most trees in the larch forest in September 2004, and a large amount of carbon $\left(36 \mathrm{MgC} \mathrm{ha}^{-1}\right)$ was removed from the site for commercial use, whereas 11 $\mathrm{MgC} \mathrm{ha} \mathrm{C}^{-1}$ of coarse woody debris (CWD), such as uprooted stumps, was left. The structure of the forest changed microclimate (Table 1; Fig. 2). R. idaeus is a pioneer species in northern Japanese forests (Toyooka \& Sugawara, 1980a,b). R. idaeus grew rapidly and extensively, and eventually became dominant (Hudson, 1959; Williams, 1959; Whitney, 1982). The seeds of $R$. idaeus were produced and buried in this region after the disturbance by Typhoon Toyamaru in 1954 (Tatewaki, 1961).

This site changed from a carbon sink to a source by the typhoon disturbance, because GPP was more decreased than RE (Table 1). However, NEP measured by the chamber technique can has some biases because of the difference in microclimate between inside and outside a chamber. Dore et al. (2003) reported that higher air temperature and VPD inside a chamber had a complex effect on NEP. The chamber technique overestimated NEP by $26 \%$ in 
the morning and $8 \%$ in the mid-day and the afternoon in the comparison with the eddy covariance technique (Dore et al., 2003). In our study, it is difficult to accurately separate positive and negative chamber effects on $\mathrm{CO}_{2}$ fluxes and evaluate net bias. We compared AGB in each chamber with that outside to verify whether chambers affected vegetation condition. The AGB in each chamber was determined in August 2007 from the plant lengths and stem number using an allometric equation. The AGB was not significantly different between inside and outside of the chambers $(p=0.39)$.

Higher soil temperature and lower soil moisture for the summer season adversely affected RE. The CWD left in the site functioned as a carbon source for heterotrophic respiration. However, heterotrophic respiration from uprooted stumps was very small during the growing season of 5 months in 2007 (15 gC m ${ }^{-2}$; Kito, personal communication).

The reduction in GPP after the typhoon mainly resulted from LAI reduction; the maximum LAI decreased to $39 \%$ and $42 \%$ in 2006 and 2007, respectively. The seasonal GPP variation in 2007 was similar to that before the typhoon (Hirata et al., 2007) and similar to that of the larch forests in East Asia (Saigusa et al., 2008). However, the peak time of GPP can be expected to change if species component changes, because the variation of GPP mainly depended on the $R$. idaeus phenology.

Many studies showed that a forest ecosystem changed from a carbon sink to a source after the stand-replacing disturbance. Kowalski et al. (2004) reported that GPP decreased larger than RE in mature conifer forests of Britain, Finland and France after clear-cut. Takagi et al. (2009) observed that harvesting decreased GPP and RE to one-third and two-third, respectively, in a conifer-broadleaf mixed forest in Hokkaido, and RE had been relatively stable for 3 years following harvest, whereas GPP increased. These results of reductions in GPP and RE were similar to our results. However, Amiro et al. (in press) reported that RE was relatively invariant through the disturbance by fire and harvest in North America, 
whereas some reduction in RE during the early succession stage was observed at some sites. At our site, daily mean NEP during July-September was $-0.8,-0.3$ and $-0.8 \mathrm{gC} \mathrm{m}^{-2} \mathrm{~d}^{-1}$ in 2006 , 2007 and 2008, respectively. Those $\mathrm{CO}_{2}$ emissions were smaller than those in a Swedish forest a half year after the Gudrun storm hit $\left(-3.8 \mathrm{gC} \mathrm{m}^{-2} \mathrm{~d}^{-1}\right.$; Lindroth et al., 2009) and that in a Russian forest 2 years after windthrow $\left(-2.0 \mathrm{gC} \mathrm{m}^{-2} \mathrm{~d}^{-1}\right.$; Knohl et al., 2002). The smaller $\mathrm{CO}_{2}$ emission at our site probably resulted from the rapid vegetation regeneration and the longer growing season. Rapid vegetation recovery and the consequent increase of GPP are important for mitigating carbon emissions after the disturbance.

Toyooka et al. (1992) reported that $R$. idaeus had been dominant for 6-8 years in disturbed forests in central Hokkaido after the catastrophic typhoon Toyamaru in 1954. Archambault et al. (1998) showed that $R$. idaeus had been abundant for 10 years after logging in Canadian forests, and that $R$. idaeus colonies were considered to prevent germination and growth of tree species. Toyooka et al. (1992) also reported that the number of surviving saplings throughout the typhoon was an important factor to determine whether major trees were able to grow well after the disturbance throughout the following 30 years. At this site, $R$. idaeus has the potential to dominate for at least a decade during the early succession stage. The domination of $R$. idaeus would prevent regeneration of major tree species and further increase in GPP. Drastic changes in the carbon balance would occur again when tree species have grown.

\section{Conclusions}

The larch plantation was transformed by the typhoon disturbance to a shrubland dominated by red raspberry (Rubus idaeus). As a result, the forest changed from a carbon sink to a source. Vegetation regeneration caused an increase of GPP and decreased net $\mathrm{CO}_{2}$ emissions. However, this ecosystem will continue to be a weak $\mathrm{CO}_{2}$ source or carbon neutral 
for the following several years, because $R$. idaeus is expected to dominate and hampered the growth of major tree species.

It is important to mitigate carbon emissions following a typhoon disturbance from the perspective of global warming. In the near future, intense typhoon is expected to occur more frequently in East Asia, and consequently, forest ecosystems will be damaged more extensively and severely. Nevertheless, rapid reforestation is difficult because of shortages of funds and labor.

\section{Acknowledgements}

We thank the Hokkaido Regional Office of the Forestry Agency for allowing the use of the site, Nobuko Saigusa and the staff of CIGER for managing the study site, Ryuichi Hirata for providing flux and meteorological data before the typhoon disturbance, Takeo Yuzu and Rei Fujita for providing vegetation data and Ray Leuning for constructive comments. This study was supported by JSPS Kakenhi 17310017 and JSPS A3 Foresight program CarboEastAsia. 


\section{References}

Archambault, L., Morissette, J., Bernier-Cardou, M., 1998. Forest succession over a 20-year period following clearcutting in balsam fir-yellow birch ecosystems of eastern Québec, Canada. For. Ecol. Manage. 102, 61-74.

Amiro, B.D., Barr, A.G., Barr, J.G., Black, T.A., Bracho, R., Brown, M., Chen, J., Clark, K.L., Davis, K.J., Desai, A.R., Dore, S., Engel, V., Fuentes, J.D., Goldstein, A.H., Goulden, M.L., Kolb, T.E., Lavigne, M.B., Law, B.E., Margolis, H.A., Martin, T., McCaughey, J.H., Misson, L., Montes-Helu, M., Noormets, A., Randerson, J.T., Starr, G., Xiao, J., 2010. Ecosystem carbon dioxide fluxes after disturbance in forests of North America. J. Geophys. Res. Biogeosciences 115, doi:10.1029/2010JG001390.

Baldocchi, D., 2008. 'Breathing' of the terrestrial biosphere: lessons learned from a global network of carbon dioxide flux measurement system. Aust. J. Bot. 56, 1-26.

Boone, R.D., Nadelhoffer K.J., Canary, J.D., Kaye, J.P., 1998. Roots exert a strong influence on the temperature sensivity of soil respiration. Nature 396, 570-572.

Dore, S., Hymus, G.J., Johnson, D.P., Hinkle, C.R., Valentini, R., Drake, B.G., 2003. Cross validation of open-top chamber and eddy covariance measurements of ecosystem $\mathrm{CO}_{2}$ exchange in a Florida scrub-oak ecosystem. Global Change Biol. 9, 84-95.

Foster, D.R., Boose, E.R., 1992. Patterns of forest damage resulting from catastrophic wind in central New England. J. Ecol. 80, 79-98.

Fujimori, T., 1995. Relationships between stand ages and wind resistances of stand-forest damage by Typhoon 7 in 1959 in the Tokyo regional forestry office, Japan. J. Jpn. For. Soc. 77, 602-605.

Goulden, M.L, Mcmillan, A.M.S., Winston, G.C., Rocha, A.V., Manies, K.L., Harden, J.W., Bond-Lamberty, B.P., 2011. Patterns of NPP, GPP, respiration, and NEP during boreal forest succession. Global Change Biol. 17, 855-871. 
Hirano, T., Hirata, R., Fujinuma, Y., Saigusa, N., Yamamoto, S., Harazono, Y., Takada, M., Inukai, K., Inoue, G., 2003. $\mathrm{CO}_{2}$ and water vapor exchange of a larch forest in northern Japan. Tellus 55B, 244-257.

Hirata, R., Hirano, T., Saigusa, N., Fujinuma, Y., Inukai, K., Kitamori, Y., Takahashi, Y., Yamamoto, S., 2007. Seasonal and interannual variations in carbon dioxide exchange of a temperate larch forest. Agric. For. Meteorol. 147, 110-124.

Hokkaido Forestry Research Institute, 2004. Flash report on wind damage caused by Typhoon No. 18 in 2004 (in Japanese). Kohshunai Seasonal Rep. 137, pp. 1-12.

Hudson, J.P., 1959. Effects of environment on Rubus idaeus L. I. Morphology and development of the raspberry plant. J. Hortic. Sci. 34, 163-169.

Ide, R., Nakaji, T., Oguma, H., 2010. Assessment of canopy photosynthetic capacity and estimation of GPP by using spectral vegetation indices and the light-response function in a larch forest. Agric. For. Meteorol. 150, 389-398.

IPCC, 2007. Climate Change 2007: The AR4 Synthesis Report. Contribution of Working Groups I, II and III to the Fourth Assessment Report of the Intergovernmental Panel on Climate Change [Core Writing Team, Pachauri, R.K. and Reisinger, A. (Eds.)], Geneva, Switzerland, 104 pp.

Knohl, A., Kolle, O., Minayeva, T.Y., Milyukova, I.M., Vygodskaya, N.N., Foken, T., Schulze, E., 2002. Carbon dioxide exchange of a Russian boreal forest after disturbance by wind throw. Global Change Biol. 8, 231-246.

Kowalski, A.S., Loustau, D., Berbigier, P., Manca, G., Tedeschi, V., Borghetti, M., Valentini, R., Kolari, P., Berninger, F., Rannik, Ü., Hari, P., Rayment, M., Mencuccini, M., Moncrieff, J., Grace, J., 2004. Paired comparisons of carbon exchange between undisturbed and regenerating stands in four managed forests in Europe. Global Change Biol. 10, 1707-1723. 
Kuboyama, H., Zheng, Y., Oka, H., 2003. Study about damage probabilities on major forest climatic risks according to age-classes (in Japanese with English summary). J. Jpn. For. Soc. 85, 191-198.

Law, B.E., Ryan, M.G., Anthoni, P.M., 1999. Seasonal and annual respiration of a ponderosa pine ecosystem. Global Change Biol. 5, 169-182.

Law, B.E., Sun, O.J., Campbell, J., Van Tuyl, S., Thornton, P.E., 2003. Changes in carbon storage and fluxes in a chronosequence of ponderosa pine. Global Change Biol. 9, $510-524$

Lee, M., Lin, T., Vadeboncoeur, M.A., Hwong, J., 2008. Remote sensing assessment of forest damage in relation to the 1996 strong typhoon Herb at Lienhuachi experimental forest, Taiwan. For. Ecol. Manage. 255, 3297-3306.

Liang, N., Inoue, G., Fujinuma, Y., 2003. A multichannel automated chamber system for continuous measurement of forest soil $\mathrm{CO}_{2}$ efflux. Tree Physiol. 23, 825-832.

Liang, N., Nakadai, T., Hirano, T., Qu, L., Koike, T., Fujinuma, Y., Inoue, G., 2004. In situ comparison of four approaches to estimating soil $\mathrm{CO}_{2}$ efflux in a northern larch (Larix kaempferi Sarg.) forest. Agric. For. Meteorol. 123, 97-117.

Lindroth, A., Lagergren, F., Grelle, A., Klemedtsson, L., Langvall, O., Weslien, P., Tuulik, J., 2009. Storms can cause Europe-wide reduction in forest carbon sink. Global Change Biol. 15, 346-355.

Mabry, C.M., Hamburg, S.P., Lin, T., Horng, F., King, H., Hsia, Y., 1998. Typhoon disturbance and stand-level damage patterns at a subtropical forest in Taiwan. Biotropica 30, 238-250.

Magnani, F., Mencuccini, M., Borghetti, M., Berbigier, P., Berninger, F., Delzon, S., Grelle, A., Hari, P., Jarvis, P.G., Kolari, P., Kowalski, A.S., Lankreijer, H., Law, B.E., Lindroth, A., Loustau, D., Manca, G., Moncrieff, J.B., Rayment, M., Tedeschi, V., Valentini, 
R., Grace, J., 2007. The human footprint in the carbon cycle of temperate and boreal forests. Nature 447, 840-850.

Matsuura, Y., Sasa, K., 2000. Estimation for storage and changes in carbon accumulated in larch ecosystems (in Japanese). Study on the interaction between atmosphere and biosphere for establishing methods of evaluation carbon dioxide absorption by forest (Final Report), Global Environment Research Fund, pp. 7-22.

Merrens, E.J., Peart, D.R., 1992. Effects of hurricane damage on individual growth and stand structure in a hardwood forest in New Hampshire, USA. J. Ecol. 80, 787-795.

Nilsson, C., Stjernquist, I., Bärring, L., Peter, S., Jönsson, A.M., Samuelsson, H., 2004. Recorded storm damage in Swedish forests 1901-2000. For. Ecol. Manage. 199, $165-173$

Reichstein M., Tenhunen J.D., Roupsard O., Ourcival, J., Rambal, S., Miglietta, F., Peressotti, A., Pecchiari, M., Tirone, G., Valentini, R., 2002. Severe drought effects on ecosystem $\mathrm{CO}_{2}$ and $\mathrm{H}_{2} \mathrm{O}$ fluxes at three Mediterranean evergreen sites: revision of current hypotheses? Global Change Biol. 8, 999-1017.

Saigusa, N., Yamamoto, S., Hirata, R., Ohtani, Y., Ide, R., Asanuma, J., Gamo, M., Hirano, T., Kondo, H., Kosugi, Y., Li, S., Nakai, Y., Takagi, K., Tani, M., Wang, H., 2008. Temporal and spatial variations in the seasonal patterns of $\mathrm{CO}_{2}$ flux in boreal, temperature, and tropical forest in East Asia. Agric. For. Meteorol. 148, 700-713.

Saito, S., 2002. Effects of a severe typhoon on forest dynamics in a warm-temperate evergreen broad-leaved forest in southwestern Japan. J. For. Res. 7, 137-143.

Sanada, E., Shiozaki, M., Takahashi, M., 1996. Monitoring of soil properties after Typhoon damage in 1954 in the Daisetsu mountains, Hokkaido, northern Japan (in Japanese with English summary). Jpn. J. For. Environ. 38, 20-27.

Szaniawski R.K., Kielkiewicz, M, 1982. Maintenance and growth respiration in shoots and 
roots of sunflower plants grown at different root temperatures. Physiol. Plant. 54, 500-504.

Takagi, K., Fukuzawa, K., Liang, N., Kayama, M., Nomura, M., Hojyo, H., Sugata, S., Shibata, H., Fukazawa, T., Takahashi, Y., Nakaji, T., Oguma, H., Mano, M., Akibayashi, Y., Murayama, T., Koike, T., Sasa, K., Fujinuma, Y., 2009. Changes in $\mathrm{CO}_{2}$ balance under a series of forestry activities in a cool-temperate mixed forest with dense undergrowth. Global Change Biol. 15, 1275-1288.

Takafumi, H., Hiura, T., 2009. Effects of disturbance history and environmental factors on the diversity and productivity of understory vegetation in a cool-temperate forest in Japan. For. Ecol. Manage. 257, 843-857.

Takahashi, K., Yoshida, K., Suzuki, M., Seino, T., Tani, T., Tashiro, N., Ishii, T., Sugata, S., Fujito, E., Naniwa, A., Kudo, G., Hiura, T., Kohyama, T., 1999. Stand biomass, net production and canopy structure in a secondary deciduous broad-leaved forest northern Japan. Res. Bull. Hokkaido Univ. For. 56, 70-85.

Takeda, T., Oguma H., Sano, T., Yone, Y., Fujinuma, Y., 2008. Estimating the stand area density of a Japanese larch (Larix kaempferi Sarg.) plantation using a ground-based laser scanner. Agric. For. Meteorol. 148, 428-438.

Tamate, S., Kashiyama, T., Sasanuma, T., Takahashi, K., Matsuoka, H., 1977. On the distribution maps of forest wind damage by Typhoon No. 15, 1954 in Hokkaido (in Japanese with English summary). Bull. Gov. For. Exp. Sta. 289, 43-67.

Tatewaki, M., 1961. Tatewaki's iconography of vegetation of the natural forest in Japan: vegetation of the forests in the vicinity of Lake Shikotsu, Porv. Iburi, Hokkaido (in Japanese with English summary). Botany, Faculty of Agriculture, Hokkaido University, 206 pp

Thornley, J.H.M., 1976. Mathematical Models in Plant Physiology. Academic Press Inc., 
London, $318 \mathrm{pp}$.

Toyooka, H., Sugawara, S., 1980a. Studies on ecology and control of the Rubus idaeus car. aculeatissimus community (I). The establishment of the Rubus community and their buried-seed populations (in Japanese). J. Jpn. For. Soc. 62 (1), 30-32.

Toyooka, H., Sugawara, S., 1980b. Studies on ecology and control of the Rubus idaeus var. aculeatissimus community (II). Development process of the Rubus community based on the vegetative propagation (in Japanese). J. Jpn. For. Soc. 62 (2), 66-68.

Toyooka, H., Ishizuka, M., Osawa, A., Kushima, H., Kanazawa, Y., Sato, A., 1992. Forest succession over a thirty-four year period following a catastrophic windstorm in the headwaters of the river Ishikari, Hokkaido (in Japanese). Bull. For. \& For. Prod. Res. Inst. 363, 59-151.

Usbeck, T., Wohlgemuth, T., Dobbertin, M., Pfister, C., Bürgi, A., Rebetez, M., 2010. Increasing storm damage to forests in Switzerland from 1858 to 2007. Agric. For. Meteorol. 150, 47-55.

van Iersel, M.W., 2003. Short-term temperature change affects the carbon exchange characteristics and growth of four bedding plant species. J. Amer. Soc. Hortic. Sci. $128,100-106$

Wang, H., Saigusa, N., Yamamoto, S., Kondo, H., Hirano, T., Toriyama, A., Fujinuma, Y., 2004. Net ecosystem $\mathrm{CO}_{2}$ exchange over a larch forest in Hokkaido, Japan. Atmos. Environ. 38, 7021-7032.

Wang, W., Qu, J.J., Hao, X., Liu, Y., Stanturf, J.A., 2010. Post-hurricane forest damage assessment using satellite remote sensing. Agric. For. Meteorol. 150, 122-132.

Williams, I.H., 1959. Effects of environment of Rubus idaeus L. II. Field observations on the variety malling promise. J. Hortic. Sci. 34, 170-175.

Whitney, G.G., 1982. The productivity and carbohydrate economy of a developing stand of 
Rubus idaeus. Can. J. Bot. 60, 2697-2703.

Yamanoi, K., Kitamura, K., Mizoguchi, Y., Nakai, Y., 2009. Changes of carbon flux in a broadleaf deciduous forest before and after windthrow disturbance. Proc. AsiaFlux Workshop 2009, pp. 119.

Yoshida, T., Noguchi, M., 2009. Vulnerability to strong winds for major tree species in a northern Japanese mixed forest: analyses of historical data. Ecol. Res. 24, 909-919.

Yuzu, T., Fujita, R., Murakami, T., 2003. Plant biomass in Tomakomai flux research site (1) Larix kaempferi (Lamp.) Carr and understory plants (in Japanese). Trans. Meet. Hokkaido Branch Jpn. For. Soc. 51, 73-75. 


\section{Figure captions}

Figure 1. Seasonal variations in (a) aboveground biomass (AGB) and (b) leaf area index (LAI) in 2006 and 2007. The vertical bars show standard deviation ( $n$ $=10)$.

Figure 2. Seasonal variations in (a) daily mean air temperature at $14 \mathrm{~m}$ during 2001-2003 and at $1.2 \mathrm{~m}$ during 2006-2008, (b) daily photosynthetic photon flux density (PPFD), (c) daytime vapor pressure deficit (VPD; 1000-1400) at $14 \mathrm{~m}$ during 2001-2003 and at $1.2 \mathrm{~m}$ during 2006-2008, (d) daily mean soil temperature at $0.05 \mathrm{~m}$ depth during 2001-2003 and at $0.06 \mathrm{~m}$ depth during 2006-2008, and (e) soil moisture at $0.05 \mathrm{~m}$ depth during 2001-2003 and at 0.01-0.05 m depth during 2006-2008. Data were averaged every 2 weeks. The vertical bars show the standard deviation of the mean for 3 years $(n=3)$.

Figure 3. Seasonal variations in daily maximum, mean and minimum soil temperature at $0.05 \mathrm{~m}$ depth before the typhoon disturbance during 2001-2003 and at $0.06 \mathrm{~m}$ depth after that during 2006-2008. Upper and lower solid lines respectively show maximum and minimum temperatures before the typhoon, and upper and lower broken lines respectively show maximum and minimum temperature after the typhoon. Open and gray circles respectively show daily mean soil temperature before and after the typhoon. Data were averaged every 2 weeks.

Figure 4. Relation between normalized RE at $10^{\circ} \mathrm{C}$ and soil moisture at $0.05 \mathrm{~m}$ or $0.01-0.05 \mathrm{~m}$ depth from July to September (a) before and (b) after the typhoon disturbance, respectively. Regression lines were drawn if significance was inferred $(p<0.05)$. Coefficients of determination $\left(r^{2}\right)$ are also shown. 
Figure 5. Seasonal variation in the maximum GPP at light saturation $\left(P_{\max }\right)$ every 2 weeks during 2006-2008. The vertical bars show standard deviations within chambers.

Figure 6. Relation between NEP under PPFD > $1000 \mu \mathrm{mol} \mathrm{m} \mathrm{m}^{-2} \mathrm{~s}^{-1}$ and vapor pressure deficit (VPD) from July to September (a) before and (b) after the typhoon disturbance, respectively. The NEP became light-saturated at around PPFD of $1000 \mu \mathrm{mol} \mathrm{m} \mathrm{m}^{-2} \mathrm{~s}^{-1}$. Regression lines were drawn if significance was inferred $(p<0.05)$. Coefficients of determination $\left(r^{2}\right)$ are also shown.

Figure 7. Seasonal variation in (a) net ecosystem production (NEP), (b) gross primary production (GPP), and (c) ecosystem respiration (RE) during 2006-2008. The positive (negative) NEP indicated $\mathrm{CO}_{2}$ uptake (loss). Data were averaged every 2 weeks. The vertical bars show standard deviations $(n=6$ in 2006 and $n=4$ in 2007 and 2008). 
Fig. 1

(a)

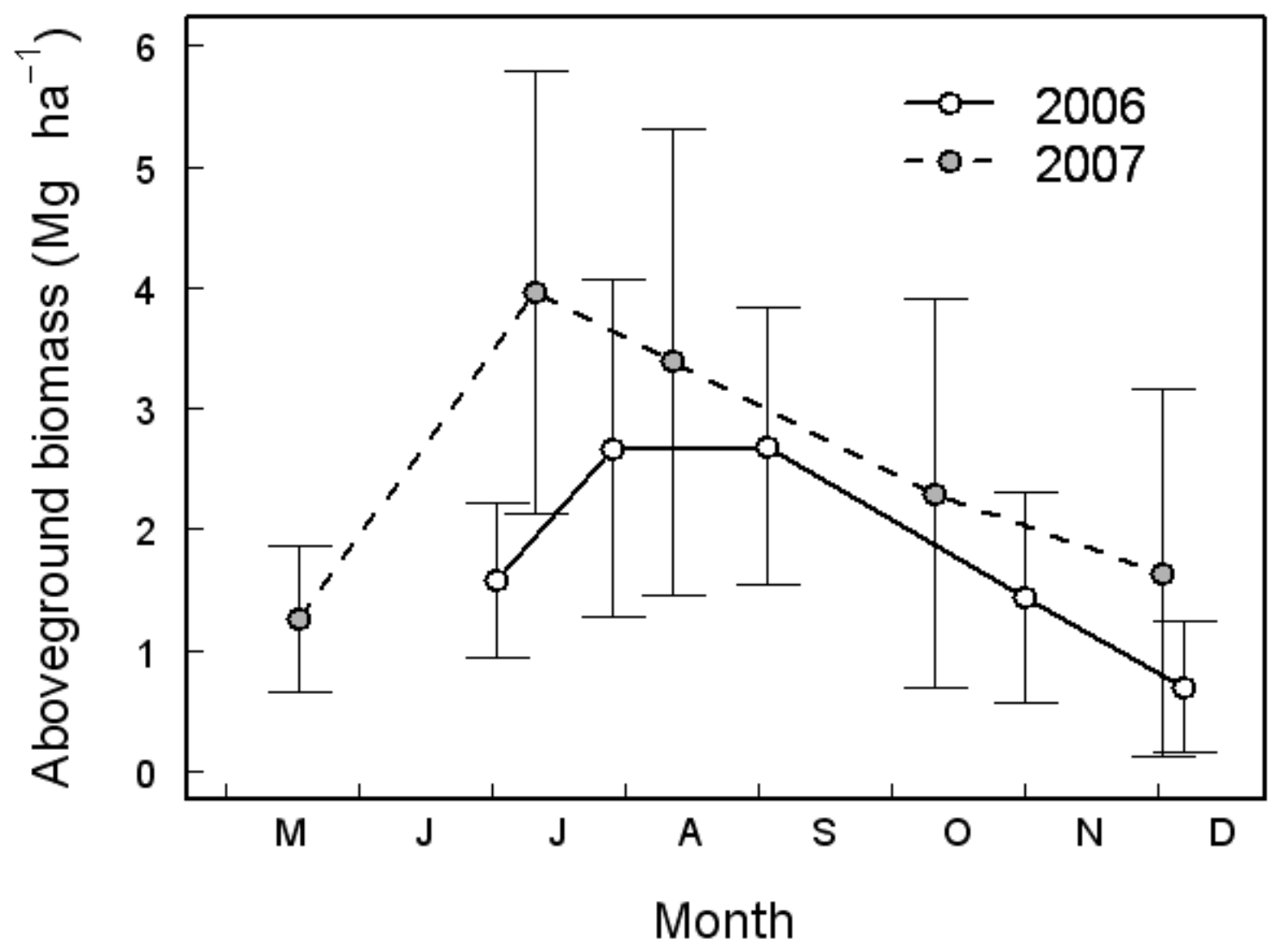

(b)

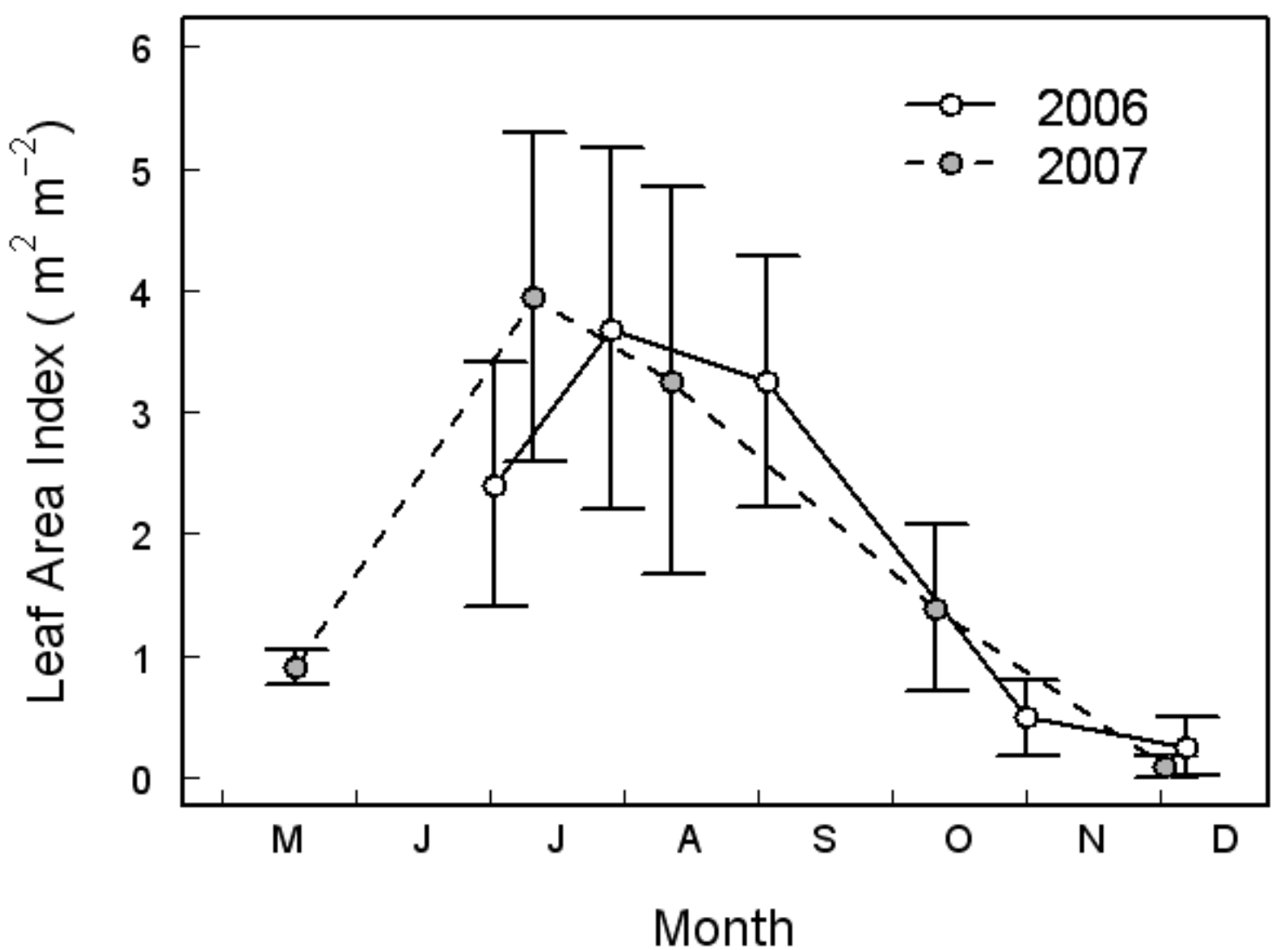


Fig. 2

(a)

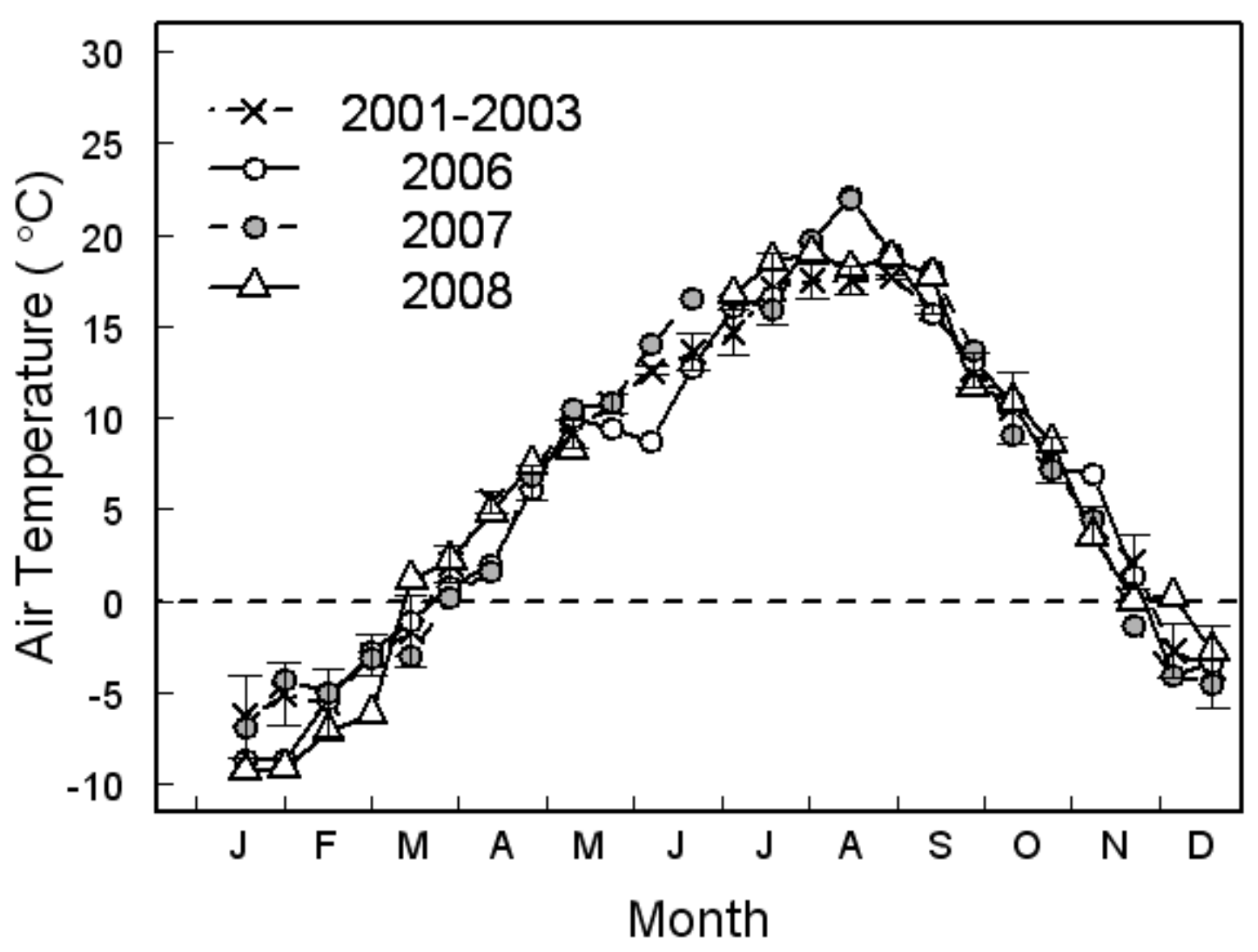

(b)

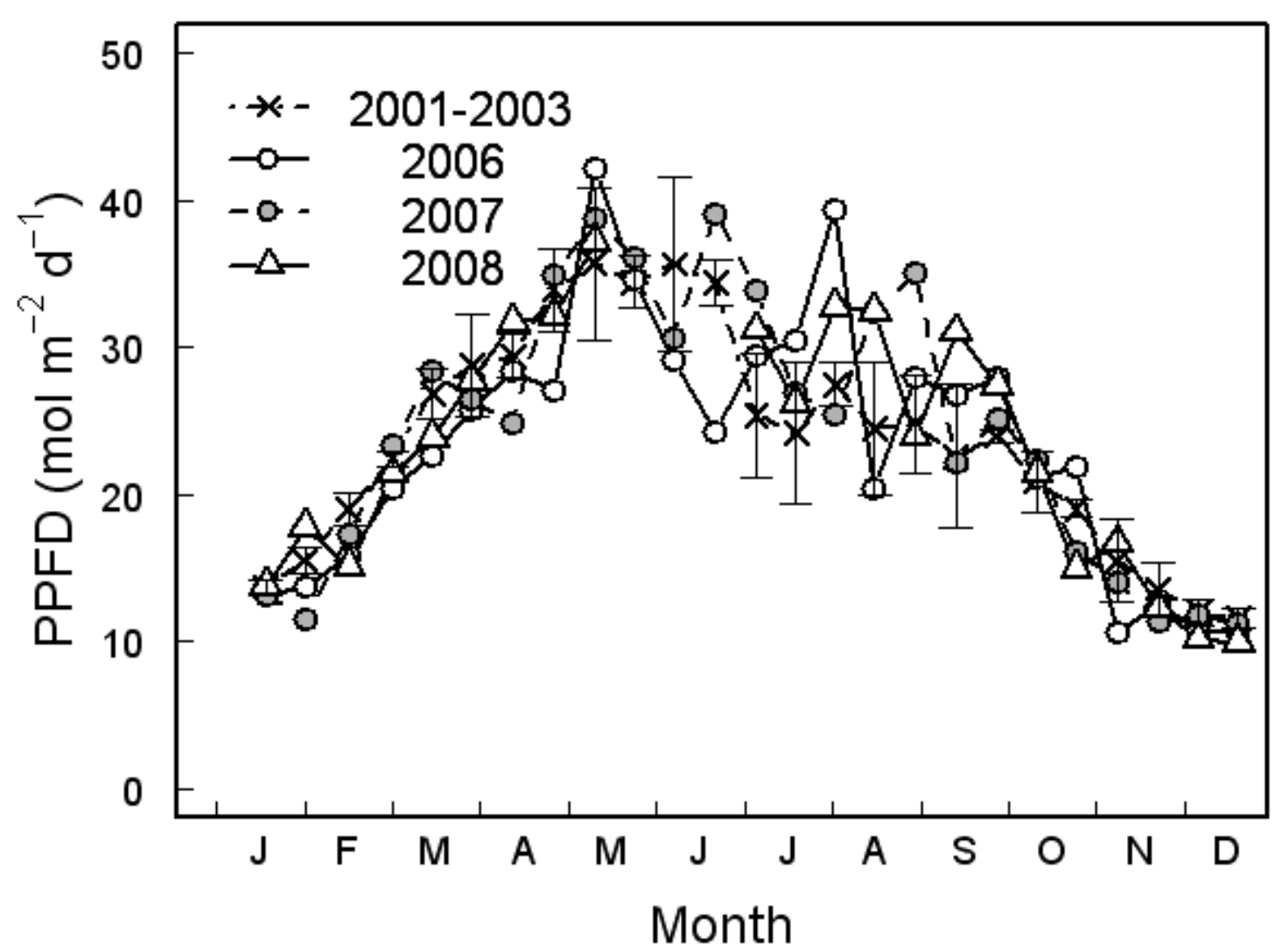


(c)

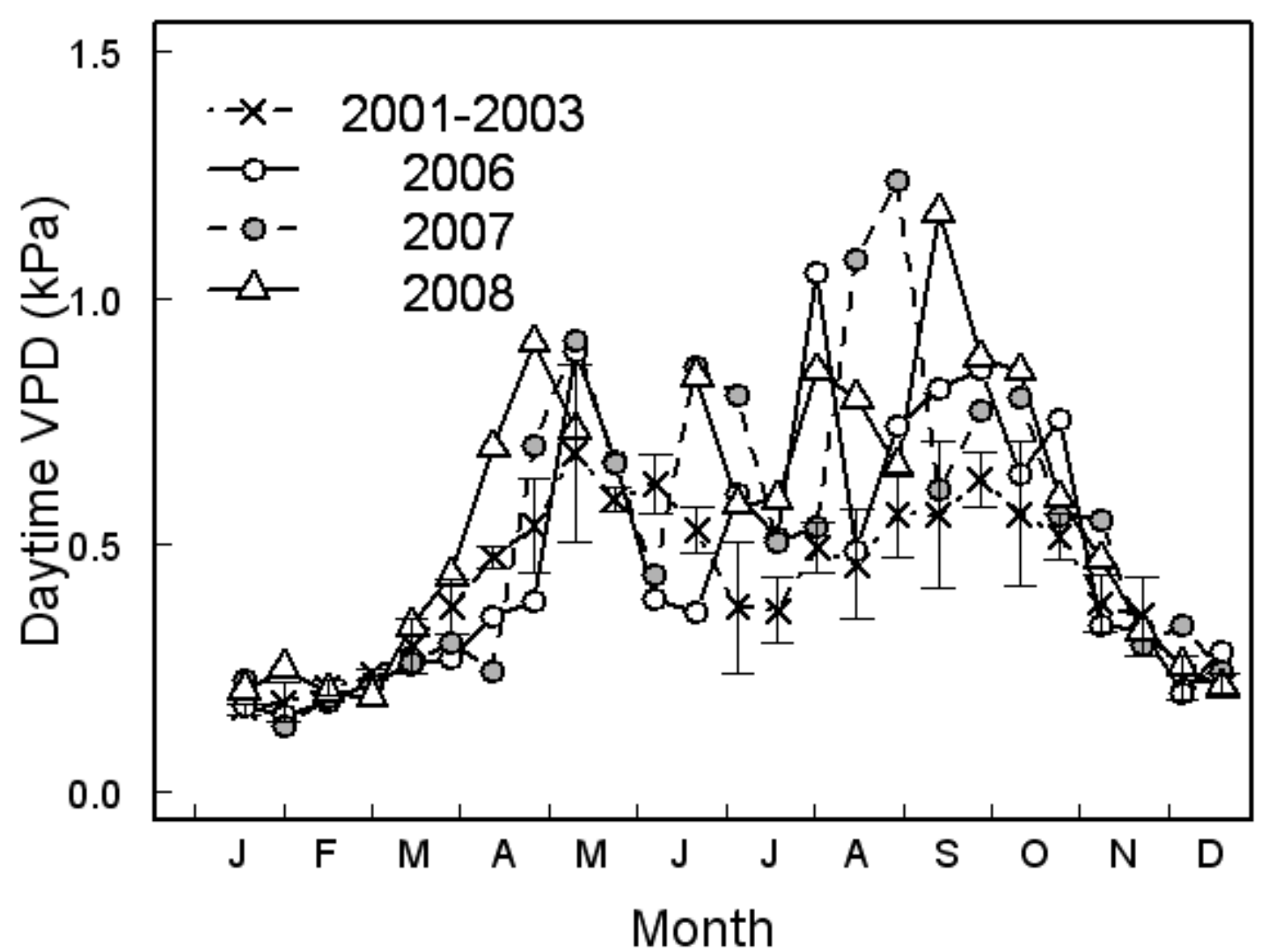

(d)

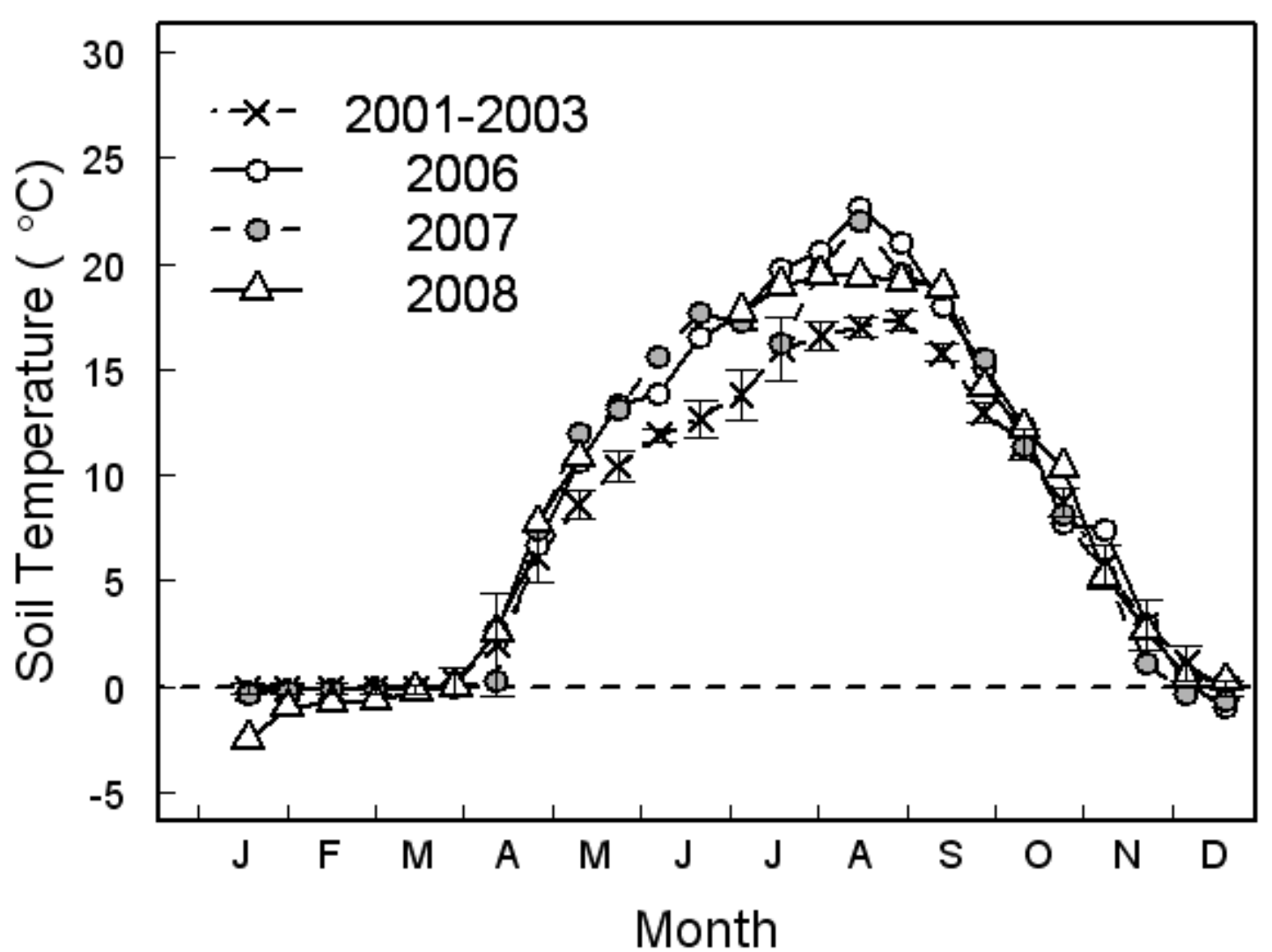


(e)

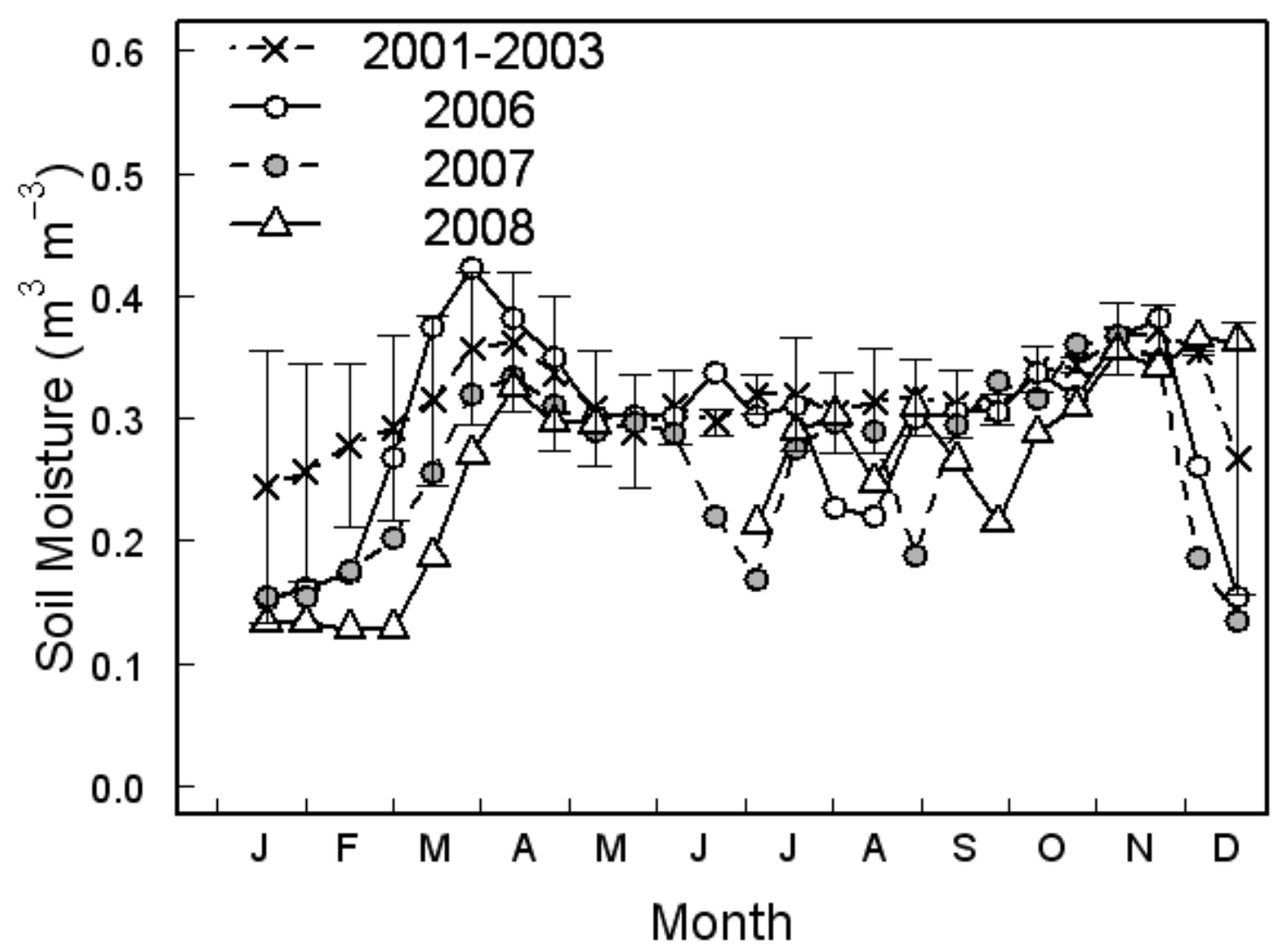


Fig. 3

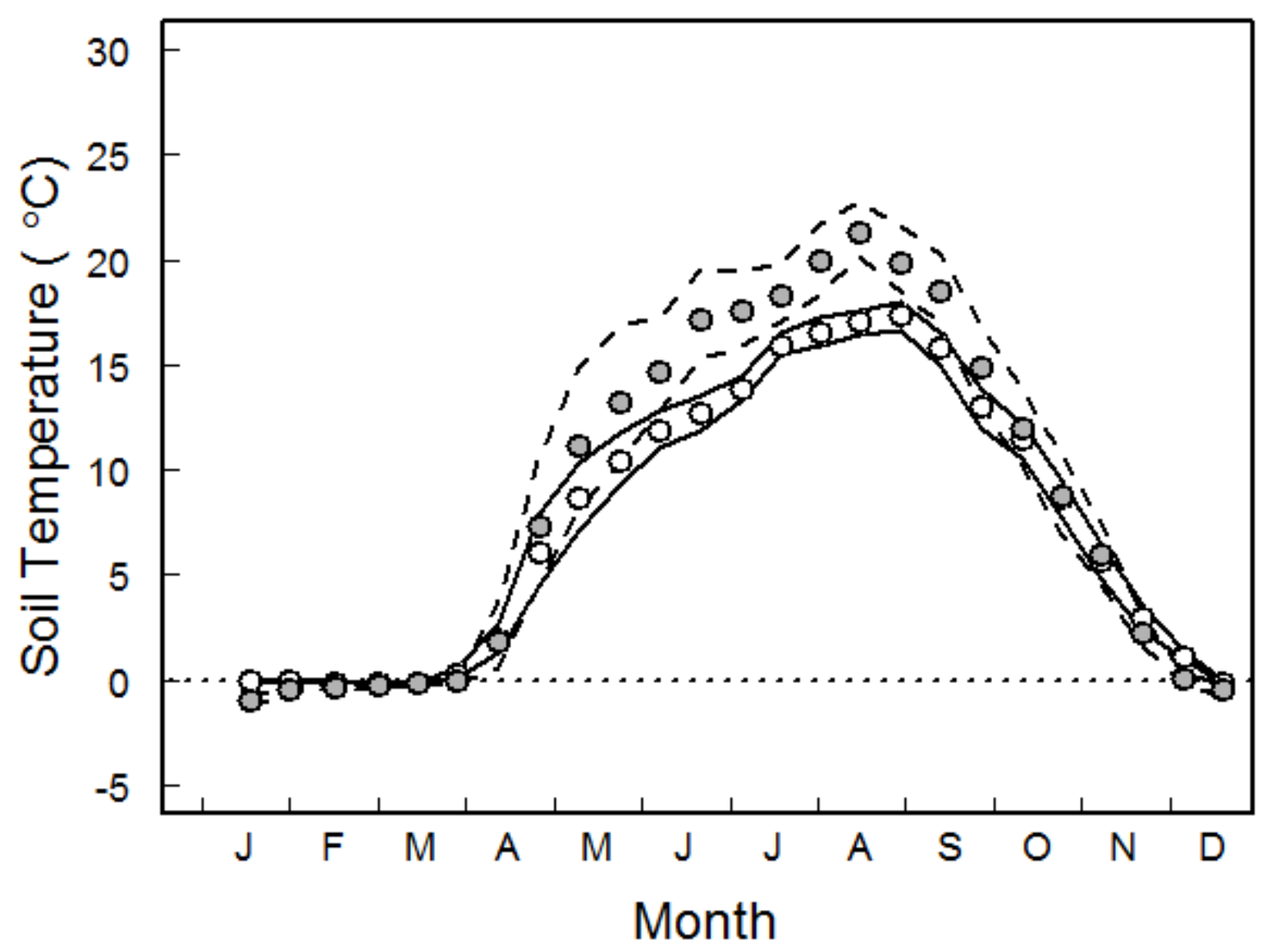


Fig. 4

(a)

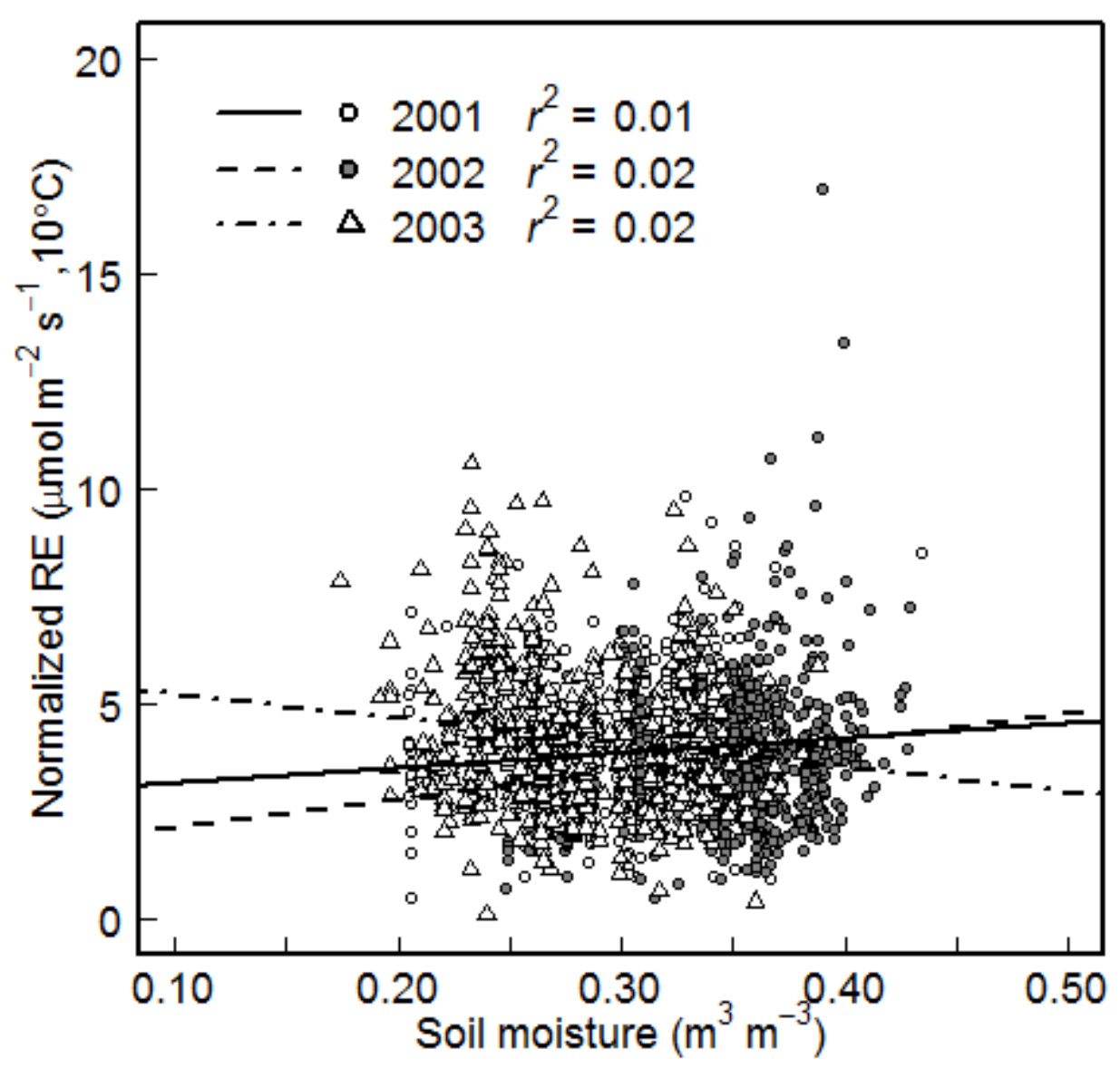

(b)

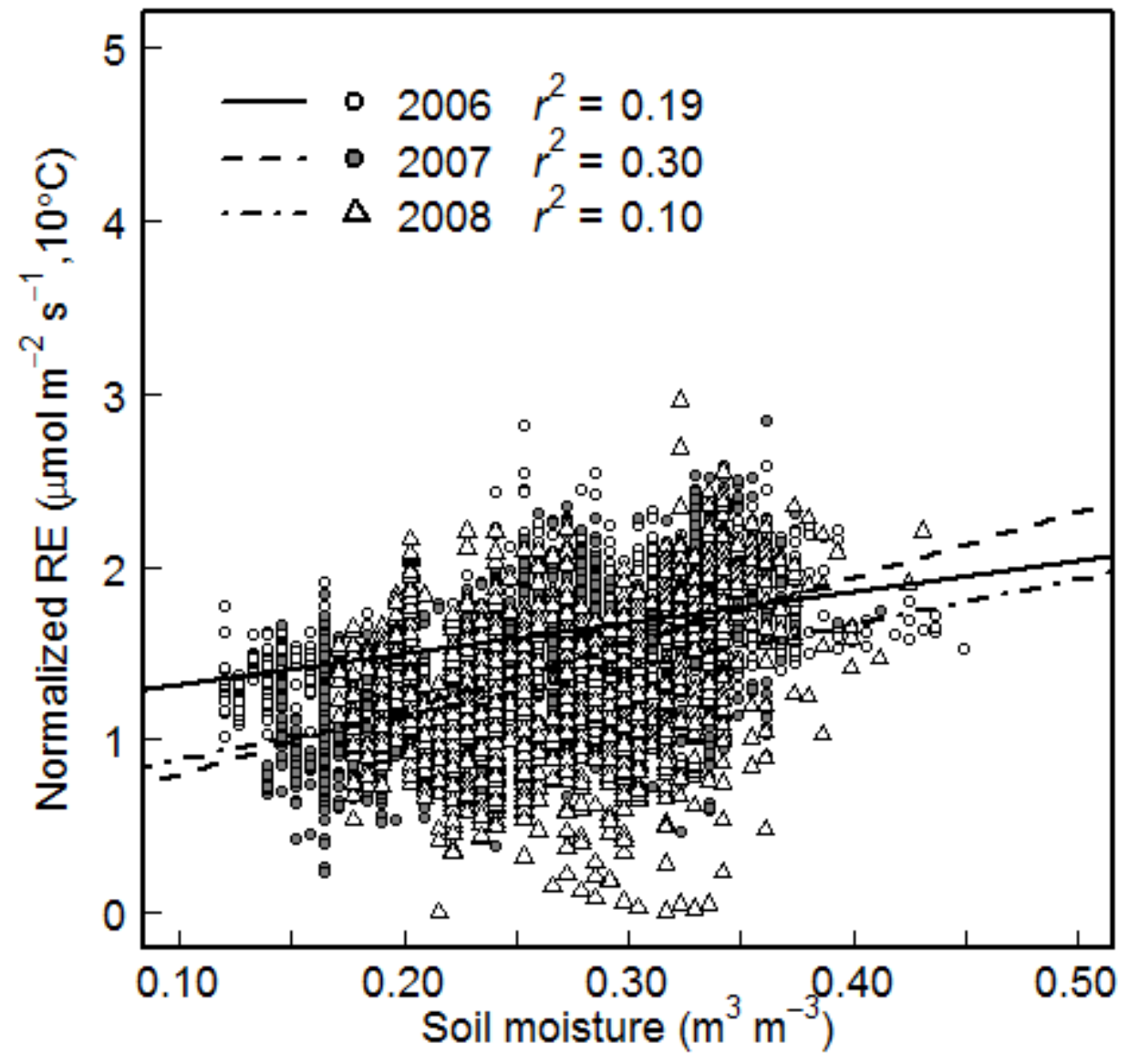


Fig. 5

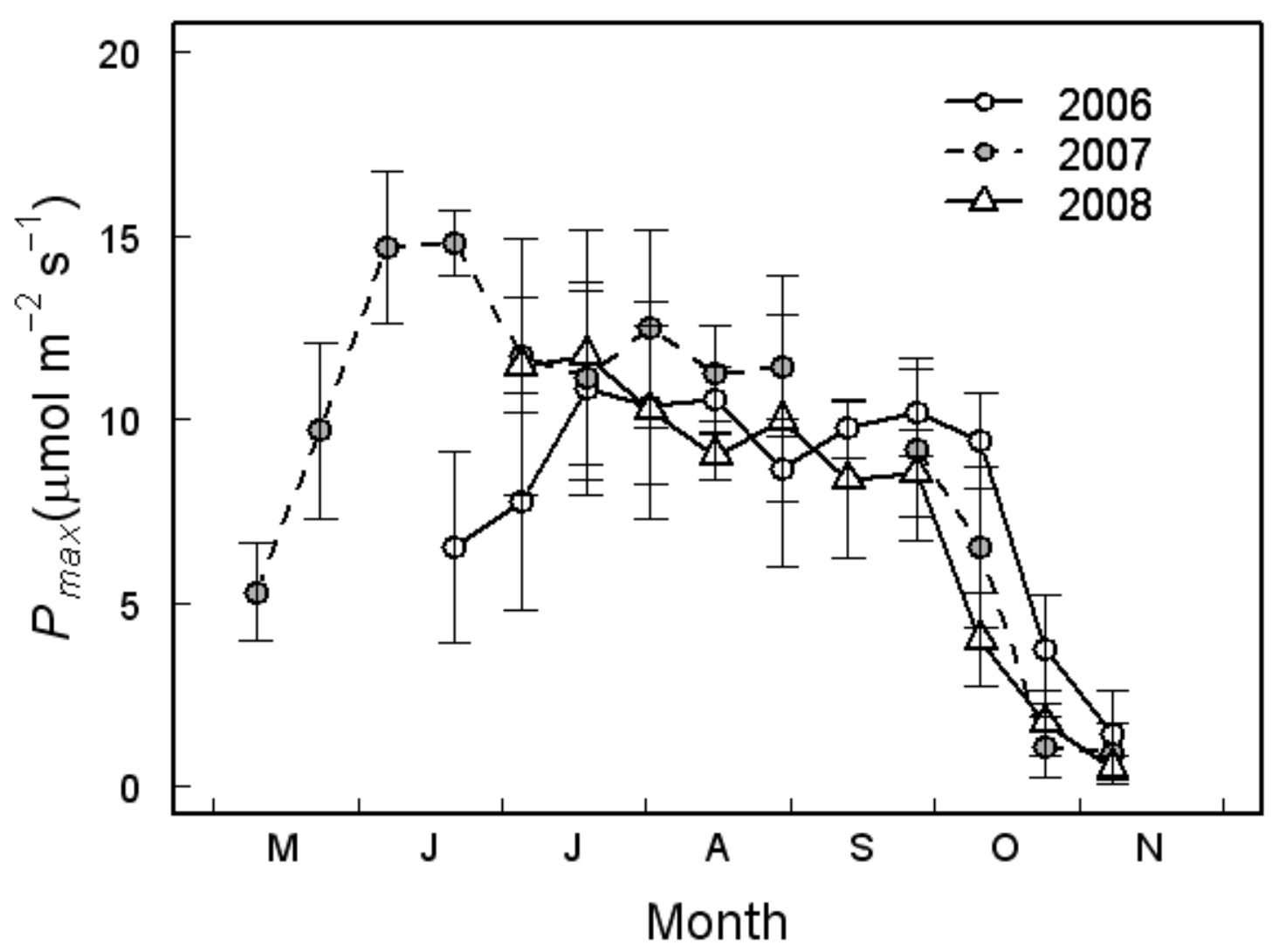


Fig. 6

(a)

(b)
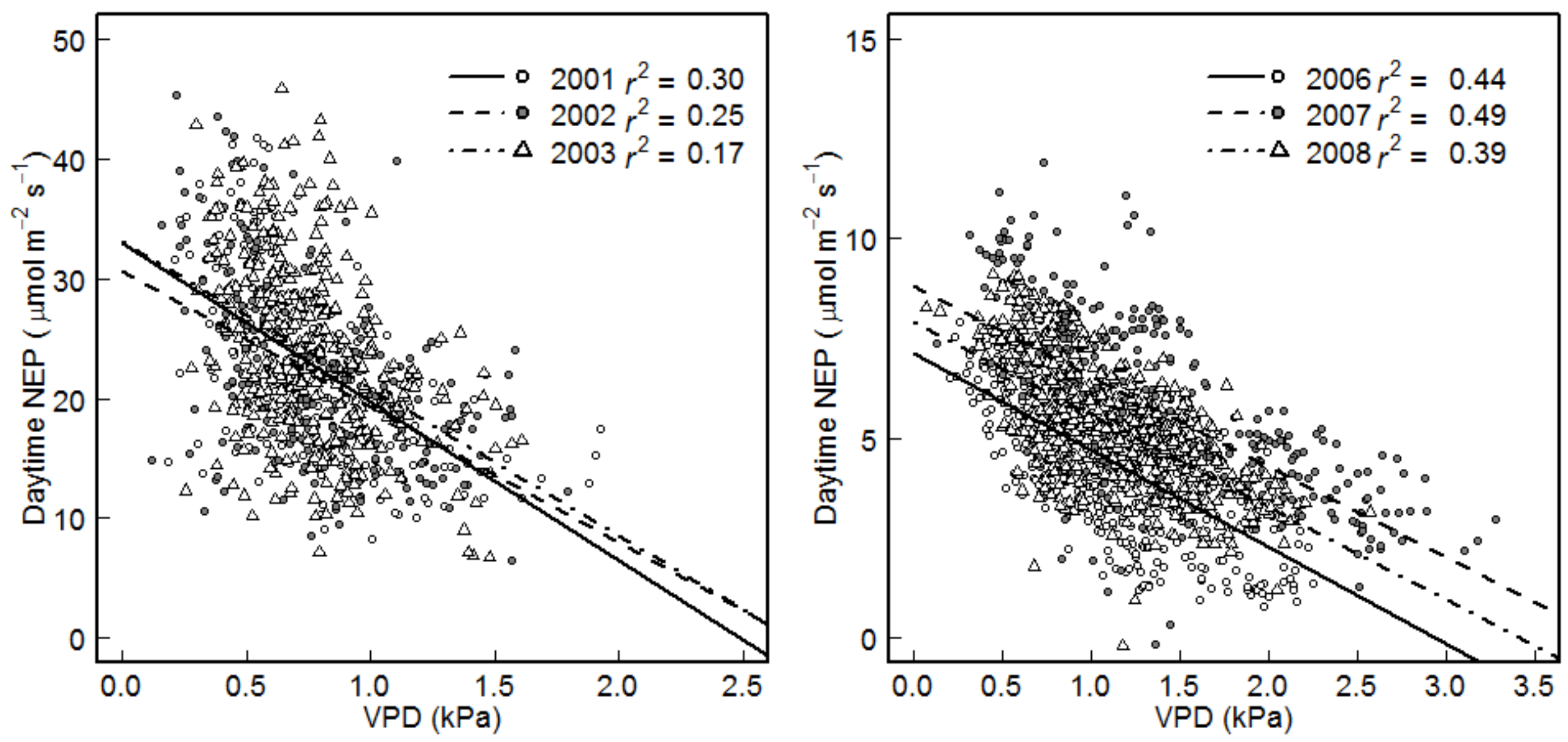
Fig. 7

(a)



(b)

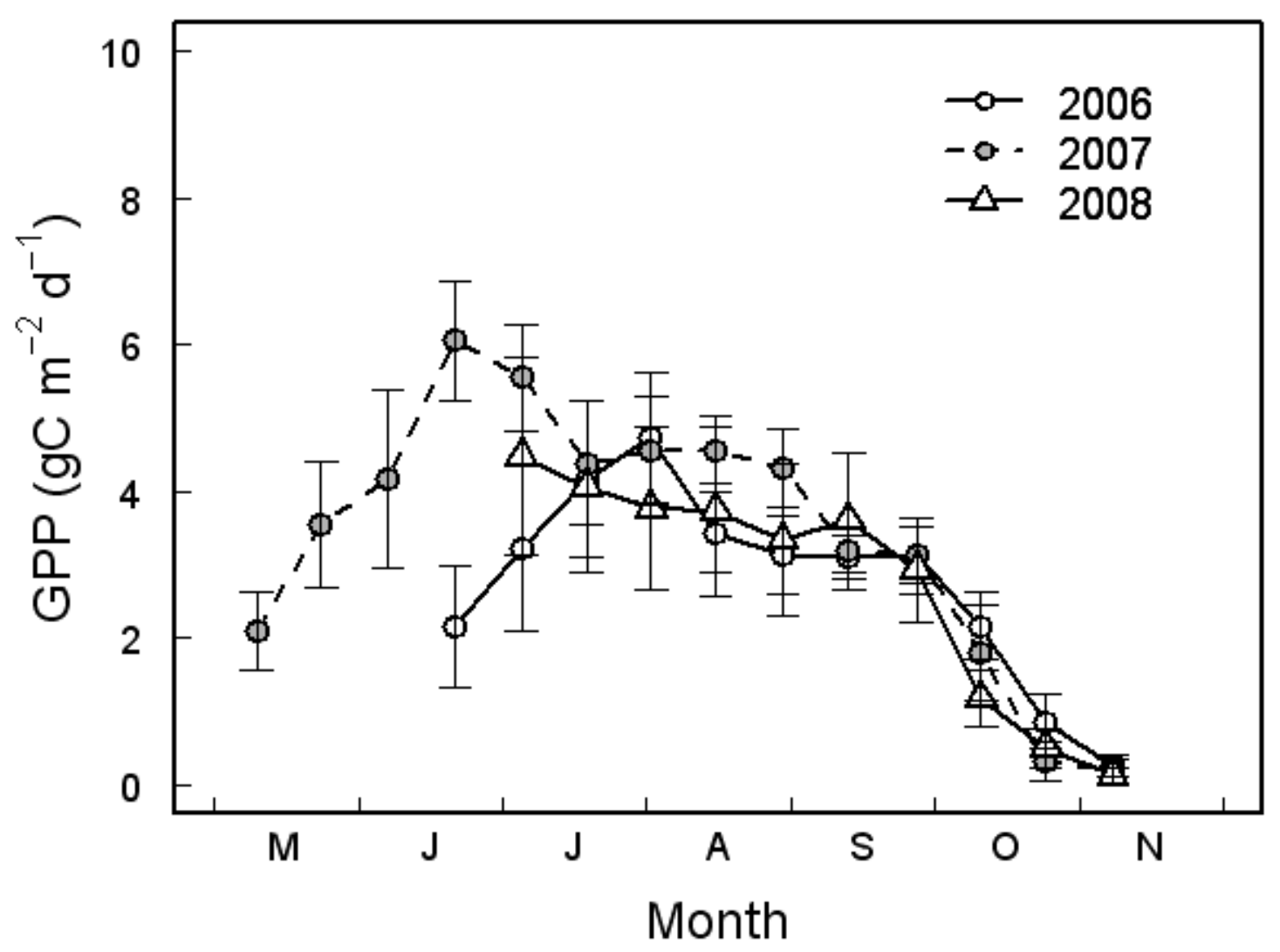


(c)

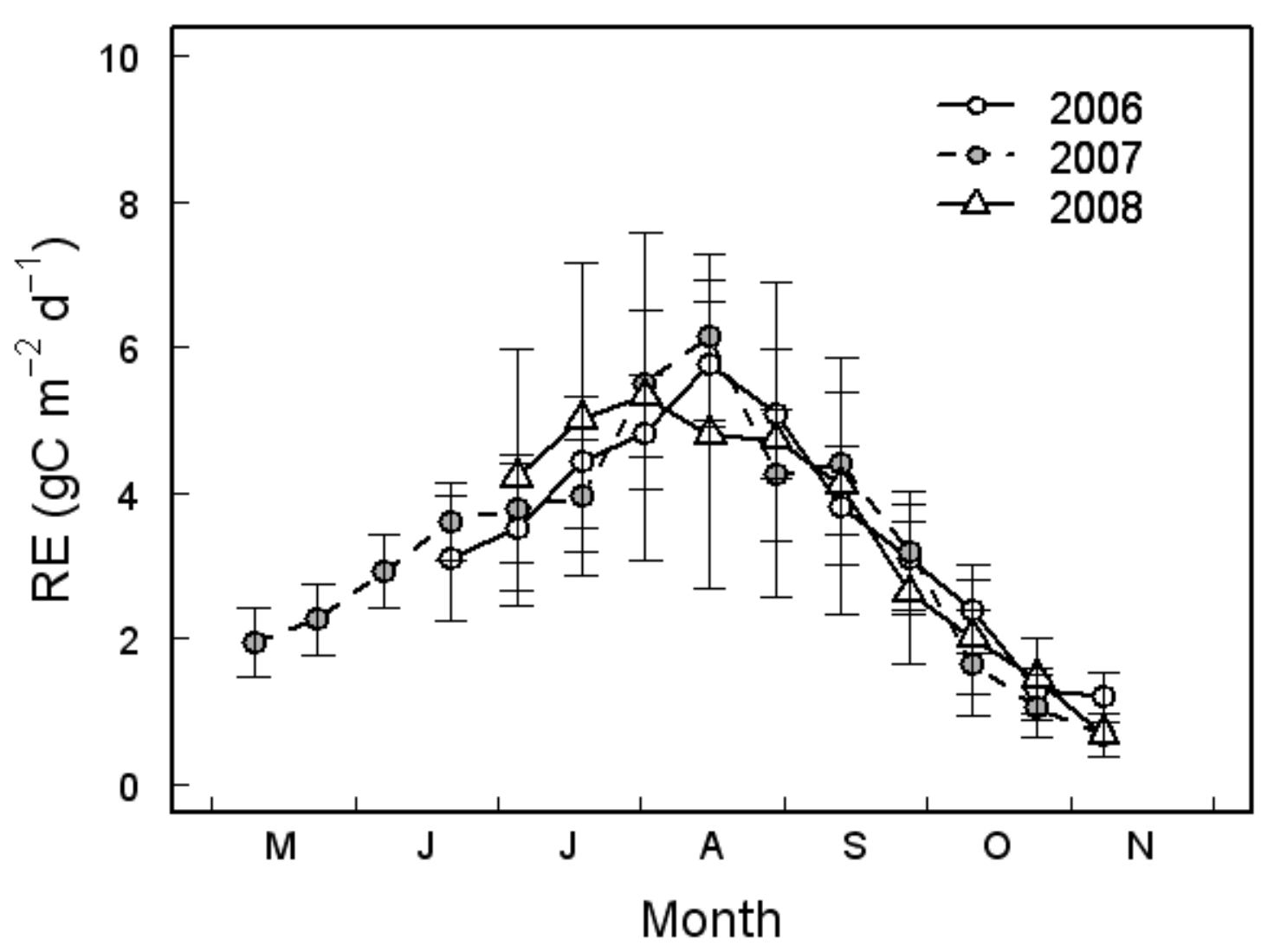


Table 1 Seasonal sums or means of $\mathrm{CO}_{2}$ exchange and microclimate before (2001-2003) and after (2006-2008) the typhoon disturbance

\begin{tabular}{|c|c|c|c|c|c|c|c|c|c|c|c|c|c|c|c|c|c|c|c|c|c|c|c|}
\hline Season & Year & $\begin{array}{l}\mathrm{NEP}^{\mathrm{a})} \\
\left(\mathrm{gC} \mathrm{m} \mathrm{m}^{-}\right.\end{array}$ & & & $\begin{array}{l}\mathrm{GPP}^{\mathrm{a})} \\
\left(\mathrm{gC} \mathrm{m}^{-}\right.\end{array}$ & & & $\begin{array}{l}\mathrm{RE} \\
\left(\mathrm{gC} \mathrm{m}^{\mathrm{a}}\right.\end{array}$ & & & $\begin{array}{l}\text { Air } \\
\text { temperature }{ }^{\text {b) }} \\
\text { ('C) }\end{array}$ & & $\begin{array}{l}\text { PPFD } \\
\left(\mathrm{mol} \mathrm{m}^{-2}\right)\end{array}$ & & & $\begin{array}{l}\text { Precipitation } \\
(\mathrm{mm})\end{array}$ & & $\begin{array}{l}\text { Daytime } \\
\mathrm{VPD}^{\mathrm{c}} \\
(\mathrm{kPa})\end{array}$ & & $\begin{array}{l}\text { Soil } \\
\text { temperature }{ }^{\mathrm{d})} \\
\left({ }^{\circ} \mathrm{C}\right)\end{array}$ & & $\begin{array}{l}\text { Soil } \\
\text { moisture }{ }^{\mathrm{e})} \\
\left(\mathrm{m}^{3} \mathrm{~m}^{-3}\right)\end{array}$ & \\
\hline 11 Jun. - 16 Nov. & 2006 & -119 & \pm & 112 & 431 & \pm & 71 & 549 & \pm & 109 & 14.2 & \multirow[b]{4}{*}{0.3} & 4028 & & & 805 & & 0.64 & & 16.0 & & 0.30 & \\
\hline 8 May - 11 Nov. & 2007 & 34 & \pm & 83 & 660 & \pm & 66 & 624 & \pm & 131 & 14.3 & & 5342 & & & 531 & & 0.74 & & 15.4 & & 0.28 & \\
\hline 28 Jun. - 20 Nov. & 2008 & -105 & \pm & 98 & 390 & \pm & 113 & 494 & \pm & 208 & 13.9 & & 3699 & & & 563 & & 0.73 & & 15.1 & & 0.28 & \\
\hline \multirow{4}{*}{28 Jun. - 11 Nov. } & 2001-2003 & 159 & \pm & 57 & 1149 & \pm & 95 & 991 & \pm & 38 & $14.0 \pm$ & & 3150 & \pm & 224 & $678 \pm$ & 74 & $0.49 \pm$ & 0.01 & $13.7 \pm$ & 0.3 & $0.32 \pm$ & 0.02 \\
\hline & 2006 & -101 & \pm & 100 & 395 & \pm & 57 & 495 & \pm & 95 & 15.0 & & 3559 & & & 651 & & 0.69 & & 16.5 & & 0.30 & \\
\hline & 2007 & -37 & \pm & 44 & 449 & \pm & 68 & 483 & \pm & 108 & 14.7 & & 3514 & & & 362 & & 0.75 & & 15.6 & & 0.29 & \\
\hline & 2008 & -101 & \pm & 96 & 388 & \pm & 112 & 489 & \pm & 206 & 14.6 & & 3560 & & & 537 & & 0.75 & & 15.8 & & 0.28 & \\
\hline
\end{tabular}

NEP, net ecosystem production; GPP, gross primary production; RE, ecosystem respiration; PPFD, photosynthetic photon flux density; VPD,

vapor pressure deficit a) Measured using the eddy covariance technique during 2001-2003 (Hirata et al., 2007) and using the automated chamber system during 2006-2008, b) Measured at 14 m during 2001-2003 and at $1.2 \mathrm{~m}$ during 2006-2008, c) Measured at 14 m during 2001-2003 and at $1.2 \mathrm{~m}$ during 2006-2008 around noon at 1000-1400, d) Measured at $0.05 \mathrm{~m}$ depth during 2001-2003 and at 0.06 m depth during 2006-2008,

e) Measured at $0.05 \mathrm{~m}$ depth during 2001-2003 and at 0.01-0.05 m depth during 2006-2008. In 2001-2003, standard deviations for three years are also shown. In 2006-2008, standard deviations of NEP, GPP and RE within chambers are also shown. 
Table 2 Parameters for the relationship between nighttime RE and soil temperature from 28 June to 11 November

\begin{tabular}{crccccccc}
\hline Year & $\mathrm{RE}_{10}$ & \multicolumn{9}{c}{$Q_{10}$} \\
\hline $2001-2003$ & 3.7 & \pm 1.2 & $3.5 \pm 0.4$ & $0.52 \pm 0.09$ \\
2006 & $1.5 \pm 0.4$ & $3.0 \pm 0.5$ & $0.59 \pm 0.18$ \\
2007 & $1.3 \pm 0.5$ & $4.2 \pm 0.6$ & $0.68 \pm 0.11$ \\
2008 & $1.3 \pm 0.5$ & $4.1 \pm 0.3$ & $0.61 \pm 0.11$ \\
\hline
\end{tabular}

$\mathrm{RE}_{10}\left(\mu \mathrm{mol} \mathrm{m} \mathrm{s}^{-2}\right)$ is the RE at the reference temperature of $10^{\circ} \mathrm{C}, Q_{10}$ is the relative increase in RE for every $10^{\circ} \mathrm{C}$ rise, and $r^{2}$ is the determination coefficient for the eq. (2). In 2001-2003, means and standard deviations for three years are shown. In 2006-2008, means and standard deviations within chambers are shown. 